\title{
Avoiding the Interaction between S-protein of SARS-CoV- 2 and ACE2, to Develop an Adjuvant Antiviral by Molecular Docking
}

\author{
José Luis Vique-Sánchez ${ }^{1, *}$ (i) \\ 1 Mexicali School of Medicine, Autonomous University of Baja California, Mexico \\ * Correspondence: jvique@uabc.edu.mx (J.L.V.-S.);
}

Scopus Author ID 57195635710

Received: 20.07.2021; Revised: 30.08.2021; Accepted: 5.09.2021; Published: 17.10.2021

\begin{abstract}
The COVID-19 pandemic continues today without specific treatment; different treatments have been proposed during this pandemic. This study proposes to develop a new drug by molecular docking, using a library of compounds, almost 500,000 compounds directed to interact in the region between the amino acids (Lys417, Tyr453, Gly496, Gln498, Thr500, Gly502, and Tyr505) in the RBD in S-protein of SARS-CoV-2, to develop a new adjuvant antiviral against COVID-19. It selected ten compounds by molecular docking with a high probability to interact in the specific region in the RBD of SARS-CoV-2 (Lys417, Tyr453, Gly496, Gln498, Thr500, Gly502, and Tyr505), to reduce the interaction with the ACE2. Also, these compounds have a high probability of being safe in humans, validated by web servers of prediction of ADME and toxicity (PreADMET) to develop a new specific adjuvant antiviral against COVID-19.
\end{abstract}

Keywords: antivirals; RBD; COVID-19; drug by docking; SARS-CoV-2.

(c) 2021 by the authors. This article is an open-access article distributed under the terms and conditions of the Creative Commons Attribution (CC BY) license (https://creativecommons.org/licenses/by/4.0/).

\section{Introduction}

The COVID-19 pandemic continues today without specific treatment; the disease caused by SARS-CoV-2 produces a wide range of signs and symptoms, mainly respiratory, gastrointestinal, and even death [1-4]. Different treatments have been proposed during this pandemic, of the first reports indicating antibiotics and an antiviral (Oseltamivir), but without evidence to effectively fight against COVID-19 [3]. New antivirals with different therapeutic targets have been developed, focusing on RNA-Dependent RNA Polymerase (RdRp), Polyproteins (3CLpro and PLpro) [5-7], Spike Protein (S-protein) [8,9], membrane fusion inhibitors (HR1 and HR2 of S-protein) [10-13] from SARS-CoV-2, or hinder the trimerization of the S-protein of SARS-CoV-2 [14], as well as directed to the ACE2 region that interacts with the RBD [15-19]. Therefore, many works are focusing on developing new drugs against COVID-19, but without results demonstrating an advantage therapeutic yet, which demonstrates the pressing demand for the development of specific drugs against COVID-19.

Due to the SARS-CoV outbreak of 2002, new drugs against therapeutic targets have been developed, where the angiotensin-converting enzyme 2 (ACE2) [20] was identified in the cell membrane, as the interaction region between this type of viruses and human cells; as well as were identified the important amino acids in the region binding domain (RBD) in the Sprotein of SARS-CoV for interacting with ACE2. [21]. 
Recently, another work proposed peptides that could affect the conformation of Sprotein and thus hindered the interaction with ACE2 [22]. ACE2 has a role as an important receptor to facilitate this virus to cross the cell membrane and develop its infectious process; even more, today, since it has been reported (December 2020) that there are mutations in RBD that could increase the transmission of this virus and decrease the effect of vaccines [23-25], and the mutation at position 501 (Tyr in instead of Asn) could increase the interaction between S-protein with ACE2. In addition, several works are used as therapeutic targets for the interaction regions between RBD in the S-protein and the ACE2, performing docking for drug repositioning and/or with chemotherapeutic libraries to search drugs or compounds that can inhibit the interaction between RBD with ACE2 [11,22,26,27].

In this study was used the crystallographic structure of the interaction between SARSCoV-2 (RBD) and ACE2 [28,29] which is demonstrating that the amino acids Lys417, Gly446, Tyr449, Tyr453, Asn487, Gly496, Thr500, Gly502, and Tyr505 in the RBD are very important to interact with ACE2. The crystallographic structure of RBD was used (PDB:6LZG), performing molecular docking directed to the amino acids mentioned, using the EXPRESSpick Collection of ChembBridge Corp. with almost 500,000 compounds, to determine the compounds that could reduce the interaction between SARS-CoV-2 and ACE2; with these results compounds will be proposed to develop a new drug against COVID-19.

\section{Materials and Methods}

\subsection{Preparation of receptor protein and definition of the binding site.}

Atomic coordinates of the Region Binding Domain (RBD) were obtained from the Protein Data Bank (PDB:6LZG). The structure was used as protein targets for docking procedures. The protonation and energy minimization of the PDB file was performed using Molecular Operating Environment (MOE) software with the default parameters and the CHARMM27 force field [30,31]. The region interacts in RBD in amino acids: Lys417, Tyr453, Gly496, Gln498, Thr500, Gly502, and Tyr505 [28].

\subsection{Compound library.}

The EXPRESS-pick Collection Stock of the small molecule screening library from Chembridge Corp. was used for docking [32]. This collection of small molecule screening compounds contains over 500,000 chemical compounds that fulfill the druggable properties of Lipinski's rules $[33,34]$ and cover a broad area of chemical space.

\subsection{Molecular docking.}

For molecular docking, following the reported methodology $[35,36]$. High-throughput virtual molecular docking was carried out $[32,37]$ by the software AutoDock and MOE, using default parameters (Placement: Triangle Matcher, Rescoring 1: London $\Delta \mathrm{G}$, Refinement: Forcefield, Rescoring 2: London $\Delta \mathrm{G}$, for each ligand up to 100 conformations were generated and saved).

\subsection{Calculation of the free binding energy $\left(\Delta G_{\text {binding }}\right)$.}

The binding affinity of each complex (Ligand-protein) was estimated by the ratio of General Born vs. Volume Integral (GB/VI), using parameters in MOE [38,39]. General Born 
or non-bonded interaction energies comprise Van der Waals, Coulomb electrostatic interactions, and implied solvent interaction energies [39].

\subsection{Selection of the best ten compounds.}

Each compound was simulated with up to 100 conformations, to select the best 10 compounds, the average of the $\Delta \mathrm{G}_{\text {binding }}$ interaction value of up to 30 conformers of each compound was calculated with Excel (Microsoft-365) following the reported methodology [35,36], the description of chemical properties by PhysChem - ACD/Labs [40], the theoretical toxicity, carcinogenicity, and mutagenicity were considered [41]. The calculated interactions between RBD and the compounds were visualized with Ligand-interaction interactions implemented in MOE.

3. Results and Discussion

\subsection{Selection of compounds by docking.}

From docking's results, by the interaction of almost 500,000 compounds in the RBD of SARS-CoV-2 (amino acids: Lys417, Tyr453, Gly496, Gln498, Thr500, Gly502, and Tyr505, Figure 1), the selection criteria of the best compounds were based on the calculation of the average of the $\Delta \mathrm{G}_{\text {binding }}$ of each compound, using the values of conformers (23 to 30 conformers), determining an average range from -5.81 to $-6.21 \mathrm{kcal} / \mathrm{mol}^{-1}$ for the best compounds (Table 1, and details on the supplementary material Table S1). We selected 10 compounds depicted here as R1 to R10 from the Express-pick Collection Stock of the small molecule screening of Chembridge library (ChemBridge Corp.), and the analysis of the interaction of each compound with RBD was carried out with the interaction report (Table 2 and details in Table S2 - S11). Afterward, the theoretical toxicity was evaluated with two websites (Prediction of Toxicity and PreADMET web server, prediction of carcinogenicity and mutagenicity).

The description of the theoretical toxicity (Table S12), ADME characteristics (Table S13), and chemical properties of each compound (R1-R10, Table S14), are presented in the supplemental material.
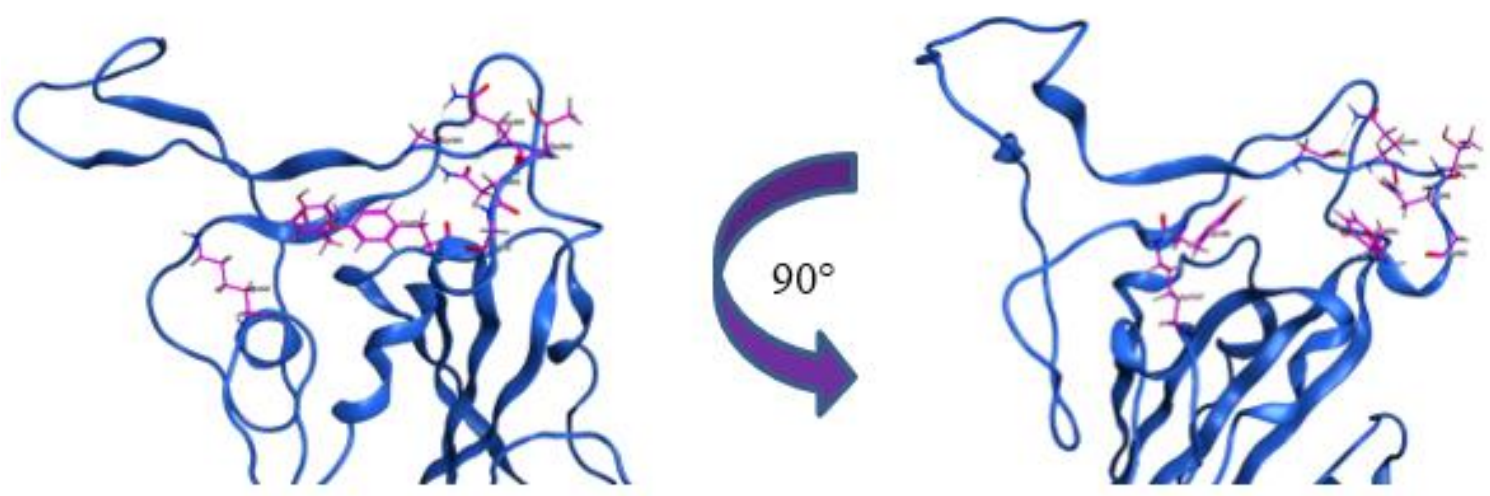

Figure 1. RBD (Blue) shows amino acids Lys417, Tyr453, Gly496, Gln498, Thr500, Gly502, and Tyr505 (Pink), as regions chosen for docking. 
Table 1. ID ChemBridge Corp., chemical name and structure of 10 best compounds, R1 to R10.

R1.- 7782385, N,N'-9H-Fluorene-2,7-diylbis[2-(3,4dimethoxyphenyl)acetamide]

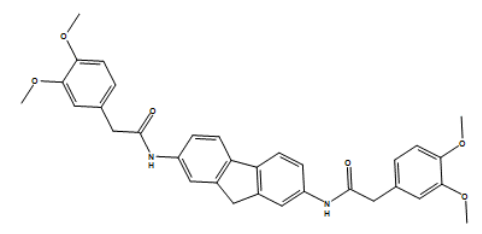

R3.- 6532012, 3,5-Bis $\{[(2-$

methoxyphenoxy)acetyl]amino $-\mathrm{N}-(2-$ methyl-2propanyl)benzamide

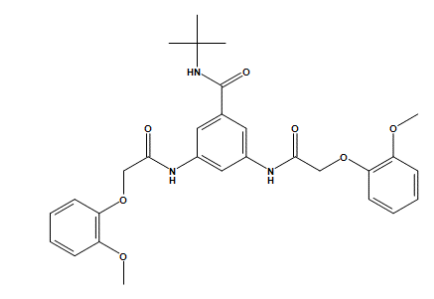

R5.- 699027, (2E)-N-(4-\{4-Methyl-5-[(1naphthylmethyl)sulfanyl]-4H-1,2,4-triazol-3yl \}phenyl)-3-phenylacrylamide

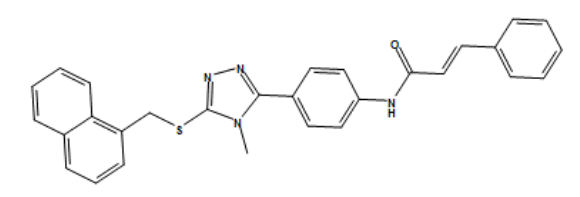

R7.- 5837947, 4-\{[4-(\{4-[(E)-(3-Allyl-4-oxo-2thioxo-1,3-thiazolidin-5-ylidene)methyl]-2methoxyphenoxy \}methyl)benzyl]oxy\}-3methoxybenzaldehyde

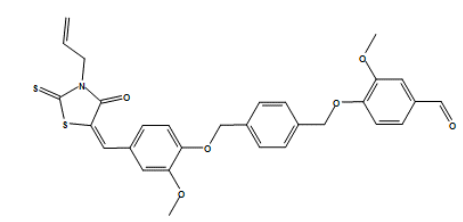

R9.- 7779797, N,N'-[Methylenebis(2-hydroxy-4,1phenylene)]bis[2-(2-methoxyphenoxy)acetamide]

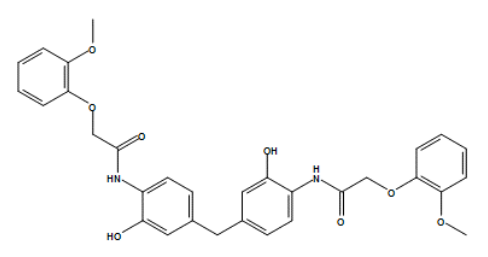

R2.- 5543060, N,N'-bis \{4-methyl-2-[(4-

methylphenyl)diazenyl]phenyl \}isophthalamide

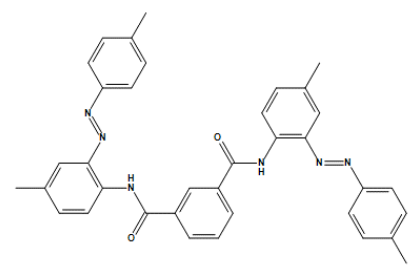

R4.- 6363182, N,N'-4,4'-Biphenyldiylbis[2-(4methylphenoxy)acetamide]

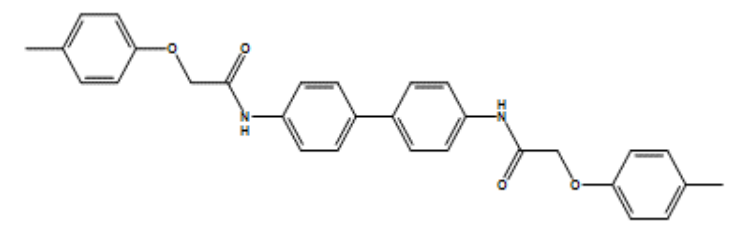

R6.- 7845819 N-Benzyl-2-\{[(\{5-[(4-methoxyphenoxy)methyl]4-methyl-4H-1,2,4-triazol-3-yl\} sulfanyl)acetyl]amino\}-4,5,6,7tetrahydro-1-benzothiophene-3-carboxamide

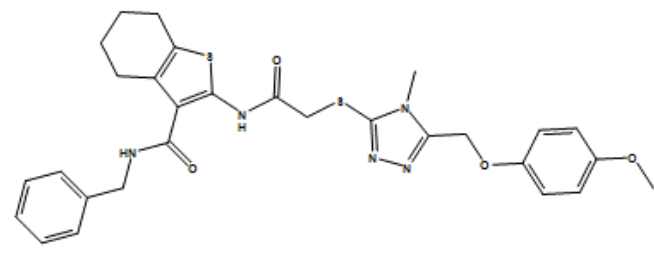

R8.- 5471668 N,N'-[(2-Phenyl-4,6-pyrimidinediyl)di-4,1phenylene]bis[2-(2-thienyl)acetamide]

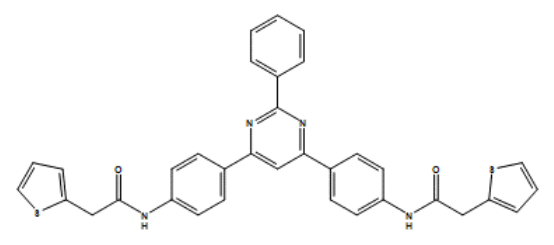

R10.- 5730468, (2Z,5Z)-3-Benzyl-2-(benzylimino)-5-\{3methoxy-4-[(4-nitrobenzyl)oxy]benzylidene $\}$-1,3-thiazolidin-4one

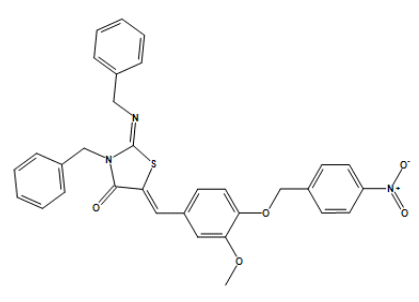


Table 2. ID compound, Smile, Interaction with residues in RBD, Number of conformers used, $\Delta \mathrm{G}_{\text {binding }}$ average (kcal/mol-1) with standard deviation (SD), Ames test and strain used (positive or negative) [43].

\begin{tabular}{|c|c|c|c|c|c|}
\hline $\begin{array}{l}\text { Compound ID } \\
\text { Chembridge } \\
\text { Corp. }\end{array}$ & Smile & $\begin{array}{l}\text { Interaction with } \\
\text { residues in ACE2 } \\
(\text { Table } S 1-S 20)\end{array}$ & $\begin{array}{l}\text { Number of } \\
\text { conformers }\end{array}$ & $\begin{array}{l}\text { Average of } \\
\Delta G_{\text {binding }} \\
\text { and SD }\end{array}$ & $\begin{array}{l}\text { PreADMET } \\
\text { Ames test } \\
\text {-TA100_10RL } \\
\text {-TA100_NA } \\
\text {-TA1535_10R } \\
\text {-TA1535_NA } \\
\end{array}$ \\
\hline R1.- 7782385 & $\begin{array}{l}\mathrm{COc} 1 \mathrm{ccc}(\mathrm{cc} 1 \mathrm{OC}) \mathrm{CC}(=\mathrm{O}) \mathrm{Nc} \\
2 \mathrm{ccc}-3 \mathrm{c}(\mathrm{c} 2) \mathrm{Cc} 4 \mathrm{c} 3 \mathrm{ccc}(\mathrm{c} 4) \\
\mathrm{NC}(=\mathrm{O}) \mathrm{Cc} 5 \mathrm{ccc}(\mathrm{c}(\mathrm{c} 5) \mathrm{OC}) \mathrm{OC}\end{array}$ & $\begin{array}{l}\text { Arg403, Glu406, } \\
\text { Gly416, Lys417, Tyr449, } \\
\text { Gly496, Gln498, Tyr505 }\end{array}$ & 25 & $-6.21 \pm 0.62$ & $\begin{array}{l}\text { Mutagen } \\
\text { y } \\
\text {-Negative } \\
\text {-Negative } \\
\text {-Negative } \\
\text {-Negative }\end{array}$ \\
\hline $\begin{array}{l}\text { Compound ID } \\
\text { Chembridge } \\
\text { Corp. }\end{array}$ & Smile & $\begin{array}{l}\text { Interaction with } \\
\text { residues in ACE2 } \\
\text { (Table } S 1-S 20)\end{array}$ & $\begin{array}{l}\text { Number of } \\
\text { conformers }\end{array}$ & $\begin{array}{l}\text { Average of } \\
\Delta G_{\text {binding }} \\
\text { and SD }\end{array}$ & $\begin{array}{l}\text { PreADMET } \\
\text { Ames test } \\
\text {-TA100_10RL } \\
\text {-TA100_NA } \\
\text {-TA1535_10R } \\
\text {-TA1535_NA } \\
\end{array}$ \\
\hline R2.- 5543060 & $\begin{array}{l}\mathrm{Cc} 1 \mathrm{ccc}(\mathrm{cc} 1) \mathrm{N}=\mathrm{Nc} 2 \mathrm{cc}(\operatorname{ccc} 2 \mathrm{~N} \\
\mathrm{C}(=\mathrm{O}) \mathrm{c} 3 \operatorname{cccc}(\mathrm{c} 3) \mathrm{C}(=\mathrm{O}) \mathrm{Nc} 4 \mathrm{c} \\
\operatorname{cc}(\operatorname{cc} 4 \mathrm{~N}=\mathrm{Nc} 5 \operatorname{ccc}(\operatorname{cc} 5) \mathrm{C}) \mathrm{C}) \mathrm{C}\end{array}$ & $\begin{array}{l}\text { Lys417, Tyr449, Tyr453, } \\
\text { Leu455, Phe456, } \\
\text { Gln493, Tyr495, Gly496, } \\
\text { Gln498, Thr500, } \\
\text { Gly502, Tyr505, }\end{array}$ & 28 & $-5.91 \pm 0.46$ & $\begin{array}{l}\text { Mutagen } \\
\text {-Positive } \\
\text {-Negative } \\
\text {-Negative } \\
\text {-Negative }\end{array}$ \\
\hline R3.- 6532012 & $\begin{array}{l}\mathrm{CC}(\mathrm{C})(\mathrm{C}) \mathrm{NC}(=\mathrm{O}) \mathrm{c} 1 \mathrm{cc}(\mathrm{cc}(\mathrm{c} 1 \\
) \mathrm{NC}(=\mathrm{O}) \mathrm{COc} 2 \mathrm{ccccc} 2 \mathrm{OC}) \mathrm{NC} \\
(=\mathrm{O}) \mathrm{COc} 3 \operatorname{ccccc} 3 \mathrm{OC}\end{array}$ & $\begin{array}{l}\text { Arg403, Arg408, } \\
\text { Gly416, Lys417, Gln493, } \\
\text { Tyr495, Gly496, Gln498, } \\
\text { Gly502 }\end{array}$ & 23 & $-5.88 \pm 0.57$ & $\begin{array}{l}\text { Non mutagen } \\
\text {-Negative } \\
\text {-Negative } \\
\text {-Negative } \\
\text {-Negative }\end{array}$ \\
\hline R4.- 6363182 & $\begin{array}{l}\mathrm{Cc} 1 \mathrm{ccc}(\mathrm{cc} 1) \mathrm{OCC}(=\mathrm{O}) \mathrm{Nc} 2 \mathrm{cc} \\
\mathrm{c}(\mathrm{cc} 2) \mathrm{c} 3 \operatorname{ccc}(\operatorname{cc} 3) \mathrm{NC}(=\mathrm{O}) \mathrm{CO} \\
\mathrm{c} 4 \mathrm{ccc}(\operatorname{cc} 4) \mathrm{C}\end{array}$ & $\begin{array}{l}\text { Arg403, Glu406, Thr415, } \\
\text { Lys417, Gly446, Tyr449, } \\
\text { Tyr453, Gly496, Gly502 }\end{array}$ & 23 & $-5.84 \pm 0.44$ & $\begin{array}{l}\text { Non mutagen } \\
\text {-Negative } \\
\text {-Negative } \\
\text {-Negative } \\
\text {-Negative }\end{array}$ \\
\hline R5.- 699027 & $\begin{array}{l}\mathrm{Cn} 1 \mathrm{c}(\mathrm{nnc} 1 \mathrm{SCc} 2 \mathrm{cccc} 3 \mathrm{c} 2 \mathrm{cccc} \\
3) \mathrm{c} 4 \mathrm{ccc}(\mathrm{cc} 4) \mathrm{NC}(=\mathrm{O}) / \mathrm{C}=\mathrm{C} / \mathrm{c} \\
5 \operatorname{ccccc} 5\end{array}$ & $\begin{array}{l}\text { Arg403, Glu406, } \\
\text { Gly416, Lys417, Gly446, } \\
\text { Tyr449, Gly496, Gln498 }\end{array}$ & 27 & $-5.83 \pm 0.52$ & $\begin{array}{l}\text { Mutagen } \\
\text {-Negative } \\
\text {-Negative } \\
\text {-Negative } \\
\text {-Negative } \\
\end{array}$ \\
\hline R6.- 7845819 & $\begin{array}{l}\mathrm{Cn} 1 \mathrm{c}(\mathrm{nnc} 1 \mathrm{SCC}(=\mathrm{O}) \mathrm{Nc} 2 \mathrm{c}(\mathrm{c} 3 \\
\mathrm{c}(\mathrm{s} 2) \mathrm{CCCC} 3) \mathrm{C}(=\mathrm{O}) \mathrm{NCc} 4 \mathrm{ccc} \\
\mathrm{cc} 4) \mathrm{COc} 5 \mathrm{ccc}(\mathrm{cc} 5) \mathrm{OC}\end{array}$ & $\begin{array}{l}\text { Arg403, Arg408, } \\
\text { Gly416, Lys417, Tyr449, } \\
\text { Tyr453, Asn460, } \\
\text { Gln493, Ser494, Tyr505 }\end{array}$ & 28 & $-5.83 \pm 0.43$ & $\begin{array}{l}\text { Non mutagen } \\
\text {-Negative } \\
\text {-Negative } \\
\text {-Negative } \\
\text {-Negative }\end{array}$ \\
\hline R7.- 5837947 & $\begin{array}{l}\text { COc1cc(ccc1OCc2 } \operatorname{ccc}(\operatorname{cc} 2) \mathrm{C} \\
\mathrm{Oc} 3 \operatorname{ccc}(\operatorname{cc} 3 \mathrm{OC}) \mathrm{C}=\mathrm{O}) / \mathrm{C}=\mathrm{C} / 4 \\
\mathrm{IC}(=\mathrm{O}) \mathrm{N}(\mathrm{C}(=\mathrm{S}) \mathrm{S} 4) \mathrm{CC}=\mathrm{C}\end{array}$ & $\begin{array}{l}\text { Arg403, Glu406, } \\
\text { Arg408, Gly416, } \\
\text { Lys417, Gly446, Tyr449, } \\
\text { Tyr453, Gly496, Gln498, } \\
\text { Thr500, Gly502, Tyr505 }\end{array}$ & 26 & $-5.83 \pm 0.49$ & $\begin{array}{l}\text { Mutagen } \\
\text {-Negative } \\
\text {-Negative } \\
\text {-Negative } \\
\text {-Negative }\end{array}$ \\
\hline R8.- 5471668 & $\begin{array}{l}\operatorname{c1ccc}(\operatorname{cc} 1) \operatorname{c} 2 \mathrm{nc}(\operatorname{cc}(\mathrm{n} 2) \cos 3 \operatorname{ccc}( \\
\operatorname{cc} 3) \mathrm{NC}(=\mathrm{O}) \mathrm{Cc} 4 \operatorname{cccs} 4) \mathrm{c} 5 \operatorname{ccc}( \\
\operatorname{cc} 5) \mathrm{NC}(=\mathrm{O}) \mathrm{Cc} 6 \operatorname{cccs} 6\end{array}$ & $\begin{array}{l}\text { Arg403, Glu406, } \\
\text { Gln409, Thr415, Lys417, } \\
\text { Asp420, Tyr449, } \\
\text { Tyr453, Gly496, } \\
\text { Gln498, Thr500, Gly502, } \\
\text { Glu504, Tyr505 }\end{array}$ & 25 & $-5.82 \pm 0.41$ & $\begin{array}{l}\text { Mutagen } \\
\text {-Negative } \\
\text {-Negative } \\
\text {-Negative } \\
\text {-Negative }\end{array}$ \\
\hline R9.- 7779797 & $\begin{array}{l}\mathrm{COc} 1 \mathrm{ccccc} 1 \mathrm{OCC}(=\mathrm{O}) \mathrm{Nc} 2 \mathrm{cc} \\
\mathrm{c}(\mathrm{cc} 2 \mathrm{O}) \mathrm{Cc} 3 \operatorname{ccc}(\mathrm{c}(\mathrm{c} 3) \mathrm{O}) \mathrm{NC}( \\
=\mathrm{O}) \mathrm{COc} 4 \operatorname{cccc} 4 \mathrm{OC}\end{array}$ & $\begin{array}{l}\text { Arg403, Lys417, } \\
\text { Gly446, Tyr449, Tyr453, } \\
\text { Ala475, Ser494, Tyr495, } \\
\text { Gly496, Gln498, Thr500, } \\
\text { Gly502, Tyr505 }\end{array}$ & 30 & $-5.82 \pm 0.56$ & $\begin{array}{l}\text { Non mutagen } \\
\text {-Negative } \\
\text {-Negative } \\
\text {-Negative } \\
\text {-Negative }\end{array}$ \\
\hline R10.- 5730468 & $\begin{array}{l}\mathrm{COc} 1 \mathrm{cc}(\mathrm{ccc} 1 \mathrm{OCc} 2 \operatorname{ccc}(\mathrm{cc} 2)[ \\
\mathrm{N}+](=\mathrm{O})[\mathrm{O}- \\
]) / \mathrm{C}=\mathrm{C} \backslash 3 / \mathrm{C}(=\mathrm{O}) \mathrm{N}(/ \mathrm{C}(=\mathrm{N} / \mathrm{Cc} \\
4 \operatorname{ccccc} 4) / \mathrm{S} 3) \mathrm{Cc} 5 \operatorname{ccccc} 5\end{array}$ & $\begin{array}{l}\text { Arg403, Arg408, } \\
\text { Gln409, Gly416, Lys417, } \\
\text { Tyr449, Tyr453, Gly496, } \\
\text { Gly502, Tyr505 }\end{array}$ & 26 & $-5.81 \pm 0.47$ & $\begin{array}{l}\text { Mutagen } \\
\text {-Positive } \\
\text {-Negative } \\
\text {-Negative } \\
\text {-Negative }\end{array}$ \\
\hline
\end{tabular}




\subsection{Interaction of compounds $R 1-R 10$ with $R B D$.}

To describe the probable interaction sites between each compound (R1 - R10) with $\mathrm{RBD}$, we analyzed up to 30 conformers of each compound with the better $\Delta \mathrm{G}_{\text {binding }}$ average values of interaction in amino acids Lys417, Tyr453, Gly496, Gln498, Thr500, Gly502, and Tyr505 (Figure 1). From the docking result (Table S2 - S11), we determined the main amino acids in RBD to interact with the ten compounds. These are Arg403, Glu406, Arg408, Gln409, Thr415, Lys417, Asp420, Gly446, Tyr449, Tyr453, Leu455, Asn460, Ala475, Gln493, Ser494, Tyr495, Gly496, Gln498, Thr500, Gly502, Glu504, and Tyr505 (Table 2). The interaction of each compound and its conformers with RBD are shown in the supplementary material (Figure S2 - S16).

\subsection{Discussion.}

Research continues to create a specific drug against SARS-CoV-2, proposing a different way to attack COVID-19 to combat the pandemic that continues to develop today. Despite the large number of works reported on new antivirals and compounds targeting SARSCoV-2, there is still no $100 \%$ effective treatment. The development of an effective treatment against COVID-19 is still under development in the world [11-13,17-19] synthetic peptides that induced conformational changes in the structure at S-protein of SARS-CoV-2 [22], characterizing and proposing potential targets for the interaction between SARS-CoV-2 and ACE2 $[17,44]$ as well as directed to the ACE2 region that interacts with the RBD $[15,16]$.

In this study, it was carried out a molecular docking aimed at the reported amino acids in the RBD of SARS-CoV-2 (Lys417, Tyr453, Gly496, Gln498, Thr500, Gly502, and Tyr505), that is important to interact with ACE2 [28,45], it was determined that residues Arg403, Glu406, Arg408, Gln409, Thr415, Lys417, Asp420, Gly446, Tyr449, Tyr453, Leu455, Asn460, Ala475, Gln493, Ser494, Tyr495, Gly496, Gln498, Thr500, Gly502, Glu504, and Tyr505 are important for the ten compounds that are proposed to interact with the RBD (Table 2 ), in addition, it has been reported that these amino acids are very important for the interaction between SARS-CoV-2 with ACE2 [20,21,28,45].

The docking results determined several interactions with hydrogen bridges of each compound proposed in the region where is the amino acid Asn501 (Table S2). It is important to emphasize that the interaction of this area with ACE2 could be prevented since that currently identified mutations in RBD that could increase the infectious process and decrease the effect of vaccines $[23,24,25]$. The mutation in position 501 in the S-protein (Tyr instead of Asn) is proposed as a factor that could increase the interaction of RBD with ACE2. Therefore, this site of interaction in ACE2 today retakes greater importance as a therapeutic target to inhibit the interaction between ACE2 and RBD (Figure 2).

The methodology followed for molecular docking has good results, previously demonstrated to the development of new drugs [35,46-48] even with patents granted of compounds against T. vaginalis [49]. For the selection of the best compounds, up to 30 conformers of each compound were analyzed, this gives us a greater probability of choosing the compounds that could interact in the amino acids Lys417, Tyr453, Gly496, Gln498, Thr500, Gly502, and Tyr505 in RBD (Figure 1), in addition, the compounds chosen are validated through two toxicity prediction web servers (Table 2 and Table S12). Thus, this could reduce the time that must be waited for to be used in humans. Therefore, we propose 
compounds (R1 - R10) with a high probability to be safe in humans, which could be tested at in vitro tests interaction of S-protein SARS-CoV-2 with ACE2.

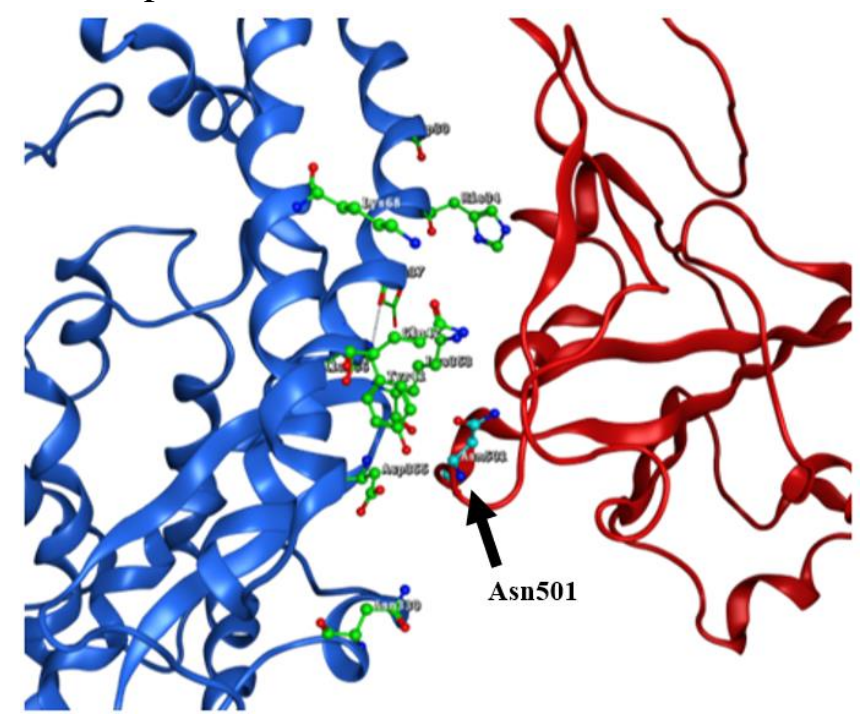

Figure 2. ACE2 (Blue) shows residues Gln24, Asp30, His34, Tyr41, Gln42, Met82, Asp330, Lys353, and Asp355 (Green). RBD of SARS-CoV-2 (Red) and Asn501 (Cyan) interacting with ACE2.

On the other hand, the new treatments could be by compounds that are directed towards the interaction regions between RBD and ACE2. This could increase the inhibitory effect and decrease the infectious process of SARS-CoV-2. Using these ten compounds in combination with some of the compounds that are already proposed against ACE2 [15,16] could stop the virus interaction with the cell receptor and thus block the formation of the RBD-ACE2 complex (Figure 3).

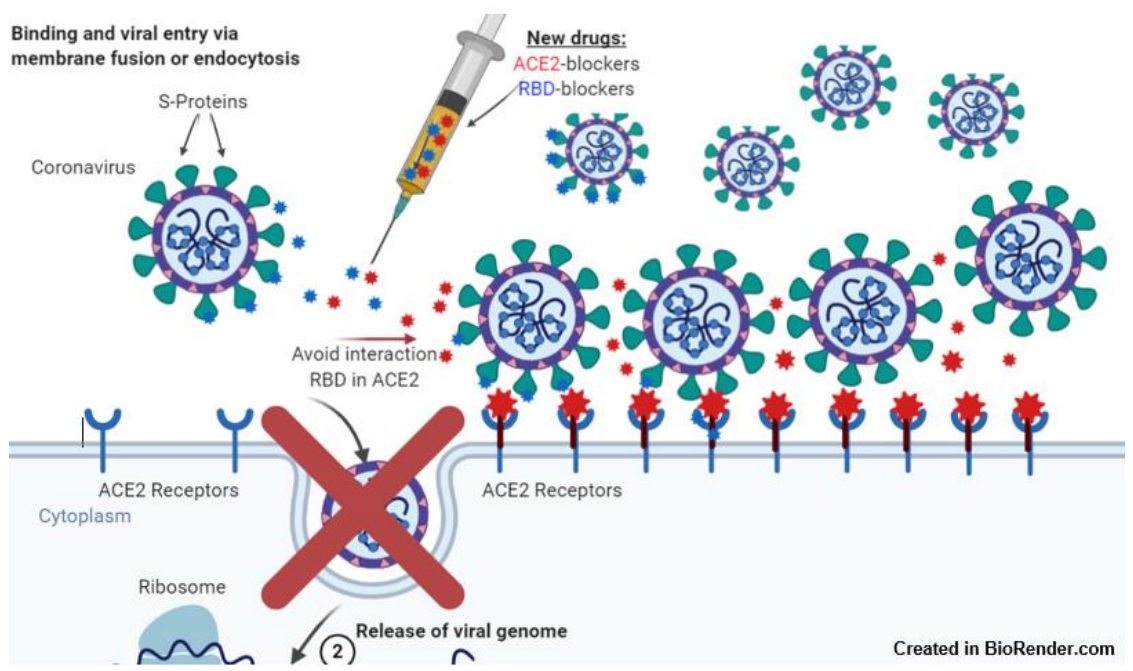

Figure 3. Combination of specific compounds that interact with the RBD of SARS-CoV-2 and ACE2 inhibits the interaction between SARS-CoV-2 and ACE2.

The proposed compounds do not have a specific use against COVID-19, nor a scientific article or registered patent. All the compounds are available to acquire them, perform in vitro assays, and determine the effect on the interaction in the RBD of SARS-CoV-2 with ACE2.

\section{Conclusions}

This study proposes ten highly probability compounds to interact in the specific region in the RBD of SARS-CoV-2 (Lys417, Tyr453, Gly496, Gln498, Thr500, Gly502, and Tyr505), 
in order to reduce the interaction with the ACE2. These ten compounds are highly likely to be safe in humans since they were validated by the PreADMET server (ADME and Toxicity Predictor). These ten compounds are available at many pharmaceutical compounds synthesis companies worldwide. To continue development at in vitro assays, determine the effect of these compounds on the RBD of SARS-CoV-2 and develop a new specific adjuvant antiviral against COVID-19 that helps combat this pandemic providing the opportunity to give a new direction to global health.

\section{Funding}

This research received no external funding.

\section{Acknowledgments}

The author is very grateful for the financial support from PTC 880-PRODEP-SEP, SNICONACyT, FMM-UABC, CISALUD-UABC, and Dr. José Manuel Avendaño Reyes.

\section{Conflicts of Interest}

The author declares no conflict of interest.

\section{References}

1. Zhao, J.; Li, X.; Gao, Y.; Huang, W. Risk factors for the exacerbation of patients with 2019 Novel Coronavirus: A meta-analysis. Int. J. Med. Sci. 2020, 17, 1744-1750, http://doi.org/10.7150/ijms.47052.

2. De Wit, E.; van Doremalen, N.; Falzarano, D.; Munster, V.J. SARS and MERS: recent insights into emerging coronaviruses. Nat. Rev. Microbiol. 2016, 14, 523-34, http://doi.org/10.1038/nrmicro.2016.81.

3. Guan, W.-J.; Ni, Z.-y.; Hu, Y.; Liang, W.; Ou, C.-Q.; He, J.-x.; Liu, L.; Shan, H.; Lei, C.-1.; Hui, D.; Du, B.; Li, L-J., Zeng, G., Yuen, K-Y., Chen, R.; Tang, C.; Wang, T.; Chen, P.; Xiang, J.; Li, S.; Wang, J.; Liang, Z.; Peng, Y.; Wei, L.; Liu, Y.; Hu, Y.; Peng, P.; Wang, J-M.; Liu, J.; Chen, Z.; Li, G.; Zheng, Z-J.; Qiu, S.; Luo, J.; Ye, C-J.; Zhu, S-Y.; Zhong, N-S. Clinical Characteristics of Coronavirus Disease 2019 in China. New England Journal of Medicine 2020, 382, http://doi.org/10.1056/NEJMoa2002032.

4. Hu, Y.; Sun, J.; Dai, Z.; Deng, H.; Li, X.; Huang, Q.; Wu, Y.; Sun, L.; Xu, Y. Prevalence and severity of corona virus disease 2019 (COVID-19): A systematic review and meta-analysis. J. Clin. Virol. 2020, 127, 104371, http://doi.org/10.1016/j.jcv.2020.104371.

5. Wang, M.; Cao, R.; Zhang, L.; Yang, X.; Liu, J.; Xu, M.; Shi, Z.; Hu, Z.; Zhong, W.; Xiao, G. Remdesivir and chloroquine effectively inhibit the recently emerged novel coronavirus (2019-nCoV) in vitro. Cell Res. 2020, 30, 269-271, http://doi.org/10.1038/s41422-020-0282-0.

6. Sheahan, T.P.; Sims, A.C.; Leist, S.R.; Schäfer, A.; Won, J.; Brown, A.J.; Montgomery, S.A.; Hogg, A.; Babusis, D.; Clarke, M.O.; Spahn, J.E.; Bauer, L.; Sellers, S.; Porter, D.; Feng, J.Y.; Cihlar, T.; Jordan, R.; Denison, M.R.; Baric, R.S. Comparative therapeutic efficacy of remdesivir and combination lopinavir, ritonavir, and interferon beta against MERS-CoV. Nat. Commun. 2020, 11, 222, http://doi.org/10.1038/s41467-019-13940-6.

7. Li, G.; De Clercq, E. Therapeutic options for the 2019 novel coronavirus (2019-nCoV). Nat. Rev. Drug Discov. 2020, 19, 149-150, http://doi.org/10.1038/d41573-020-00016-0.

8. Calligari, P.; Bobone, S.; Ricci, G.; Bocedi, A. Molecular Investigation of SARS-CoV-2 Proteins and Their Interactions with Antiviral Drugs. Viruses 2020, 12, 445, http://doi.org/10.3390/v12040445.

9. Huang, J.; Song, W.; Huang, H.; Sun, Q. Pharmacological Therapeutics Targeting RNA-Dependent RNA Polymerase, Proteinase and Spike Protein: From Mechanistic Studies to Clinical Trials for COVID-19. J. Clin. Med. 2020, 9, 1131, http://doi.org/10.3390/jcm9041131.

10. Iftikhar, H.; Ali, H.N.; Farooq, S.; Naveed, H.; Shahzad-ul-Hussan, S. Identification of potential inhibitors of three key enzymes of SARS-CoV2 using computational approach. Comput. Biol. Med. 2020, 122, 103848, http://doi.org/10.1016/j.compbiomed.2020.103848. 
11. Wu, C.; Liu, Y.; Yang, Y.; Zhang, P.; Zhong, W.; Wang, Y.; Wang, Q.; Xu, Y.; Li, M.; Li, X.; Zheng, M.; Chen, L.; Li, H. Analysis of therapeutic targets for SARS-CoV-2 and discovery of potential drugs by computational methods. Acta Pharm. Sin. B 2020, 10, 766-788, http://doi.org/10.1016/j.apsb.2020.02.008.

12. Xia, S.; Yan, L.; Xu, W.; Agrawal, A.S.; Algaissi, A.; Tseng, C.-T.K.; Wang, Q.; Du, L.; Tan, W.; Wilson, I.A.; Jiang, S.; Yang, B.; Lu, L. A pan-coronavirus fusion inhibitor targeting the HR1 domain of human coronavirus spike. Sci. Adv. 2019, 5, eaav4580, http://doi.org/10.1126/sciadv.aav4580.

13. Xia, S.; Liu, M.; Wang, C.; Xu, W.; Lan, Q.; Feng, S.; Qi, F.; Bao, L.; Du, L.; Liu, S.; Qin, C.; Sun, F.; Shi, Z.; Zhu, Y.; Jiang, S.; Lu, L. Inhibition of SARS-CoV-2 (previously 2019-nCoV) infection by a highly potent pan-coronavirus fusion inhibitor targeting its spike protein that harbors a high capacity to mediate membrane fusion. Cell Res. 2020, 30, 343-355, http://doi.org/10.1038/s41422-020-0305-X.

14. Vankadari, N. Arbidol: A potential antiviral drug for the treatment of SARS-CoV-2 by blocking trimerization of the spike glycoprotein. Int. J. Antimicrob. Agents 2020, 105998, http://doi.org/10.1016/j.ijantimicag.2020.105998.

15. Benítez-Cardoza, C.G.; Vique-Sánchez, J.L. Potential inhibitors of the interaction between ACE2 and SARSCoV-2(RBD), to develop a drug. Life Sci. 2020, 256, 117970, http://doi.org/10.1016/j.lfs.2020.117970.

16. Khelfaoui, H.; Harkati, D.; Saleh, B.A. Molecular docking, molecular dynamics simulations and reactivity, studies on approved drugs library targeting ACE2 and SARS-CoV-2 binding with ACE2. J. Biomol. Struct. Dyn. 2020, 1-17, http://doi.org/10.1080/07391102.2020.1803967.

17. Grifoni, A.; Sidney, J.; Zhang, Y.; Scheuermann, R.H.; Peters, B.; Sette, A. A Sequence Homology and Bioinformatic Approach Can Predict Candidate Targets for Immune Responses to SARS-CoV-2. Cell Host Microbe 2020, http://doi.org/10.1016/j.chom.2020.03.002.

18. Ton, A.-T.; Gentile, F.; Hsing, M.; Ban, F.; Cherkasov, A. Rapid Identification of Potential Inhibitors of SARS-CoV-2 Main Protease by Deep Docking of 1.3 Billion Compounds. Mol. Inform. 2020, http://doi.org/10.1002/minf.202000028.

19. Zhang, L.; Lin, D.; Sun, X.; Curth, U.; Drosten, C.; Sauerhering, L.; Becker, S.; Rox, K.; Hilgenfeld, R. Crystal structure of SARS-CoV-2 main protease provides a basis for design of improved $\alpha$-ketoamide inhibitors. Science 2020, 368, 409-412, http://doi.org/10.1126/science.abb3405.

20. Han, D.P.; Penn-Nicholson, A.; Cho, M.W. Identification of critical determinants on ACE2 for SARS-CoV entry and development of a potent entry inhibitor. Virology 2006, 350, 15-25, http://doi.org/10.1016/j.virol.2006.01.029.

21. Li, F.; Li, W.; Farzan, M.; Harrison, S.C. Structure of SARS coronavirus spike receptor-binding domain complexed with receptor. Science 2005, 309, 1864-8, http://doi.org/10.1126/science.1116480.

22. Souza, P.F.N.; Lopes, F.E.S.; Amaral, J.L.; Freitas, C.D.T.; Oliveira, J.T.A. A molecular docking study revealed that synthetic peptides induced conformational changes in the structure of SARS-CoV-2 spike glycoprotein, disrupting the interaction with human ACE2 receptor. Int. J. Biol. Macromol. 2020, 164, 6676, http://doi.org/10.1016/j.ijbiomac.2020.07.174.

23. Conti, P.; Caraffa, A.; Gallenga, C.E.; Kritas, S.K.; Frydas, I.; Younes, A.; Di Emidio, P.; Tetè, G.; Pregliasco, F.; Ronconi, G. The British variant of the new coronavirus-19 (Sars-Cov-2) should not create a vaccine problem. J Biol Regul Homeost Agents 2021, 35, 1-4, http://doi.org/10.23812/21-3-e.

24. Santos, J.C.; Passos, G.A. The high infectivity of SARS-CoV-2 B.1.1.7 is associated with increased interaction force between Spike-ACE2 caused by the viral N501Y mutation. BioRxiv 2021, http://doi.org/10.1101/2020.12.29.424708.

25. Luan, B.; Wang, H.; Huynh, T. Molecular Mechanism of the N501Y Mutation for Enhanced Binding between SARS-CoV-2-2's Spike Protein and Human ACE2 Receptor. BioRxiv 2021, http://doi.org/10.1101/2021.01.04.425316.

26. BR, B.; Damle, H.; Ganju, S.; Damle, L. In silico screening of known small molecules to bind ACE2 specific RBD on Spike glycoprotein of SARS-CoV-2 for repurposing against COVID-19. F1000Research 2020, 9 , 663, http://doi.org/10.12688/f1000research.24143.1.

27. Prajapat, M.; Shekhar, N.; Sarma, P.; Avti, P.; Singh, S.; Kaur, H.; Bhattacharyya, A.; Kumar, S.; Sharma, S.; Prakash, A.; Medhi, B. Virtual screening and molecular dynamics study of approved drugs as inhibitors of spike protein S1 domain and ACE2 interaction in SARS-CoV-2. J. Mol. Graph. Model. 2020, 101, 107716, http://doi.org/10.1016/j.jmgm.2020.107716.

28. Yan, R.; Zhang, Y.; Li, Y.; Xia, L.; Guo, Y.; Zhou, Q. Structural basis for the recognition of the SARS-CoV2 by full-length human ACE2. Science 2020, http://doi.org/10.1126/science.abb2762. 
29. Tai, W.; He, L.; Zhang, X.; Pu, J.; Voronin, D.; Jiang, S.; Zhou, Y.; Du, L. Characterization of the receptorbinding domain (RBD) of 2019 novel coronavirus: implication for development of RBD protein as a viral attachment inhibitor and vaccine. Cell. Mol. Immunol. 2020, http://doi.org/10.1038/s41423-020-0400-4.

30. Brooks, B.R.; Brooks, C.L.; Mackerell, A.D.; Nilsson, L.; Petrella, R.J.; Roux, B.; Won, Y.; Archontis, G.; Bartels, C.; Boresch, S.; Caflisch, A.; Caves, L.; Cui, Q.; Dinner, A.R.; Feig, M.; Fischer, S.; Gao, J.; Hodoscek, M.; Im, W., Kuczera, K.; Lazaridis, T.; Ma, J.; Ovchinnkov, V.; Paci, E.; Pastor, R.W.; Post, C.B.; Pu, J.Z.; Schaefer, M.; Tidor, B.; Venable, R.M.; Woodcock, H.L.; Wu, X.; Yang. W.; York, D.M.; Karplus, M. CHARMM: The biomolecular simulation program. J. Comput. Chem. 2009, 30, 1545-1614, http://doi.org/10.1002/jcc.21287.

31. Halgren, T.A. Merck molecular force field. I. Basis, form, scope, parameterization, and performance of MMFF94. Journal of Computational Chemistry 1996, 17, 490-519, http://doi.org/10.1002/(SICI)1096987X(199604)17:5/6<490::AID-JCC1>3.0.CO;2-P.

32. Corporation, ChemBridge Available online: http://www.chembridge.com/screening_libraries/ (accessed on December 2020).

33. Lipinski, C.A.; Lombardo, F.; Dominy, B.W.; Feeney, P.J. Experimental and computational approaches to estimate solubility and permeability in drug discovery and development settings1PII of original article: S0169-409X(96)00423-1. The article was originally published in Advanced Drug Delivery Reviews 23 (1997) 3-25.1. Advanced Drug Delivery Reviews 2001, 46, 3-26, https://doi.org/10.1016/S0169409X(00)00129-0.

34. Thangapandian, S.; John, S.; Lee, Y.; Kim, S.; Lee, K.W. Dynamic Structure-Based Pharmacophore Model Development: A New and Effective Addition in the Histone Deacetylase 8 (HDAC8) Inhibitor Discovery. Int. J. Mol. Sci. 2011, 12, 9440-9462, http://doi.org/10.3390/ijms12129440.

35. Vique-Sánchez, J. Potential inhibitors interacting in Neuropilin-1 to develop an adjuvant drug against COVID-19, by molecular docking. Bioorganic \& Medicinal Chemistry 2021, 33, 116040, http://doi.org/10.1016/j.bmc.2021.116040.

36. Benítez-Cardoza, C.G.; Vique-Sánchez, J.L. Potential inhibitors of the interaction between ACE2 and SARSCoV-2 (RBD), to develop a drug. Life Sci. 2020, 117970, http://doi.org/10.1016/j.lfs.2020.117970.

37. Soga, S.; Shirai, H.; Kobori, M.; Hirayama, N. Use of Amino Acid Composition to Predict Ligand-Binding Sites. J. Chem. Inf. Model. 2007, 47, 400-406, http://doi.org/10.1021/ci6002202.

38. Labute, P. The generalized Born/volume integral implicit solvent model: estimation of the free energy of hydration using London dispersion instead of atomic surface area. J. Comput. Chem. 2008, 29, 1693-8, http://doi.org/10.1002/jcc.20933.

39. Wadood, A.; Ghufran, M.; Hassan, S.F.; Khan, H.; Azam, S.S.; Rashid, U. In silico identification of promiscuous scaffolds as potential inhibitors of 1-deoxy- $d$-xylulose 5-phosphate reductoisomerase for treatment of Falciparum malaria. Pharmaceutical Biology 2017, 55, 19-32, http://doi.org/10.1080/13880209.2016.1225778.

40. www.acdlabs.com/ Available online: https://www.acdlabs.com/products/percepta/index.php (accessed on December 2020).

41. PreADMET Available online: https://preadmet.bmdrc.kr/toxicity/ (accessed on December 2020).

42. ProTox-II Prediction of TOXicity Available http://tox.charite.de/protox_II/index.php?site=compound_input (accessed on December 2020).

43. ADMETlab Available online: http://admet.scbdd.com/calcpre/index_sys/ (accessed on December 2020).

44. Hoffmann, M.; Kleine-Weber, H.; Schroeder, S.; Krüger, N.; Herrler, T.; Erichsen, S.; Schiergens, T.S.; Herrler, G.; Wu, N.-H.; Nitsche, A.; Muller, A.M.; Drosten, C.; Pohlmann, S. SARS-CoV-2 Cell Entry Depends on ACE2 and TMPRSS2 and Is Blocked by a Clinically Proven Protease Inhibitor. Cell 2020, http://doi.org/10.1016/j.cell.2020.02.052.

45. Tai, W.; He, L.; Zhang, X.; Pu, J.; Voronin, D.; Jiang, S.; Zhou, Y.; Du, L. Characterization of the receptorbinding domain (RBD) of 2019 novel coronavirus: implication for development of RBD protein as a viral attachment inhibitor and vaccine. Cell. Mol. Immunol. 2020, http://doi.org/10.1038/s41423-020-0400-4.

46. Vique-Sánchez, J.L.; Caro-Gómez, L.A.; Brieba, L.G.; Benítez-Cardoza, C.G. Developing a new drug against trichomoniasis, new inhibitory compounds of the protein triosephosphate isomerase. Parasitol. Int. 2020, http://doi.org/10.1016/j.parint.2020.102086.

47. Vique-Sánchez, J.L.; Jiménez-Pineda, A.; Benítez-Cardoza, C.G. Amoebicidal effect of 5,5'-[(4nitrophenyl)methylene]bis-6-hydroxy-2-mercapto-3-methyl-4(3 H )-pyrimidinone), a new drug against Entamoeba histolytica. Archiv Pharmazie 2020, http://doi.org/10.1002/ardp.202000263. 
48. Benítez-Cardoza, C.G.; Fernández-Velasco, D.A.; Vique-Sánchez, J.L. Triosephosphate Isomerase Inhibitors as Potential Drugs against Clostridium perfringens. ChemistrySelect 2020, http://doi.org/10.1002/slct.201904632.

49. Arroyo-Verástegui, R.; Ortega-López, J.; Benítez-Cardoza, C.; Vique-Sánchez, L.L.; Brieba de castro, L. gabriel; Rojo-Domínguez, A.; García-Gutiérrez, P. El uso de 5,5'- [(4-nitrofenil)-metilen]bis(6-hidroxi-2mercapto-3-metil-4(3H)-pirimidinonaTIM como tricomonicida. MX/a/2016/013109, IMPI, Mexico. 2016, https://siga.impi.gob.mx/newSIGA/content/common/principal.jsf. 


\section{Supplementary materials}

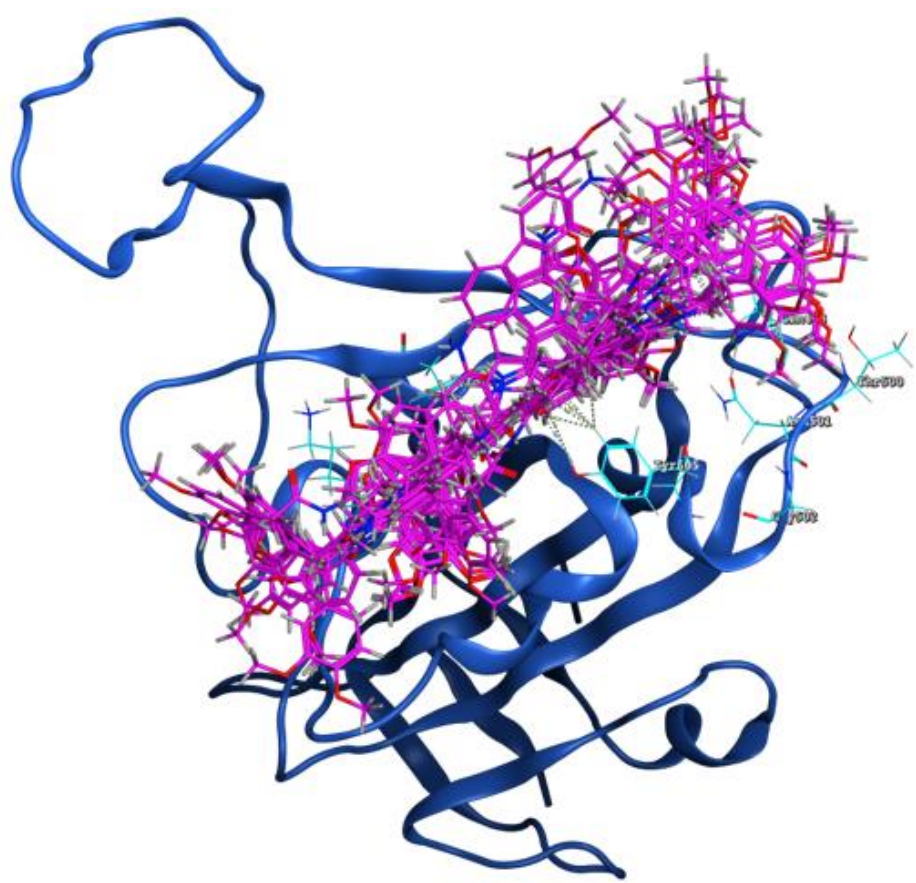

Figure S1. RBD (Blue) shows amino acids Lys417, Tyr453, Gly496, Gln498, Thr500, Gly502, and Tyr505 (Cyan), as region chosen for docking. with 25 conformers of compound R1 (Pink).

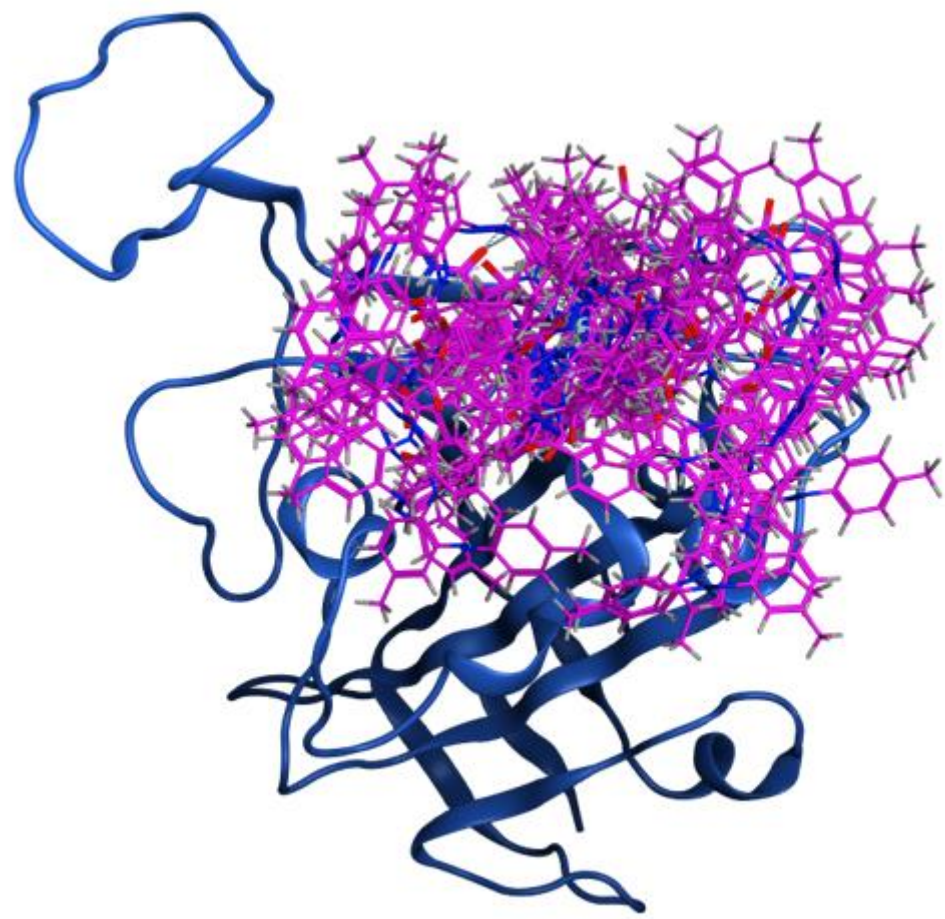

Figure S2. RBD (Blue) shows amino acids Lys417, Tyr453, Gly496, Gln498, Thr500, Gly502, and Tyr505 (Cyan), as region chosen for docking. with 28 conformers of compound R2 (Pink). 


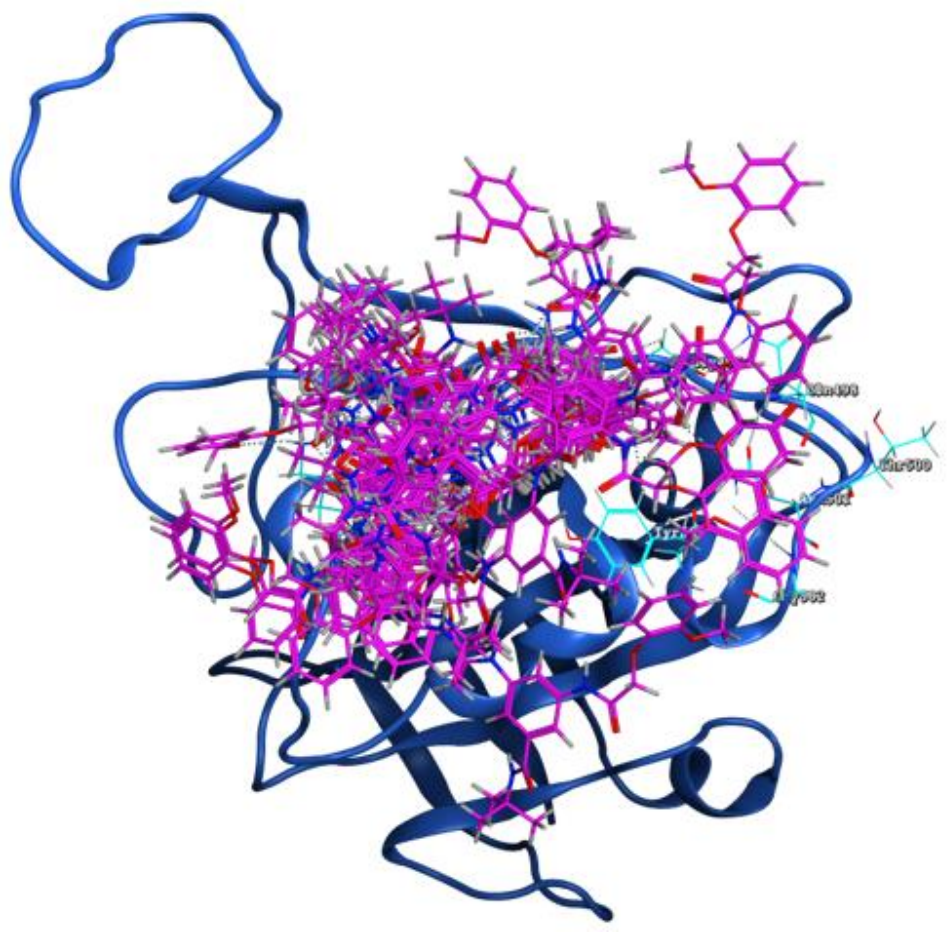

Figure S3. RBD (Blue) shows amino acids Lys417, Tyr453, Gly496, Gln498, Thr500, Gly502, and Tyr505 (Cyan), as region chosen for docking. with 23 conformers of compound R3 (Pink).

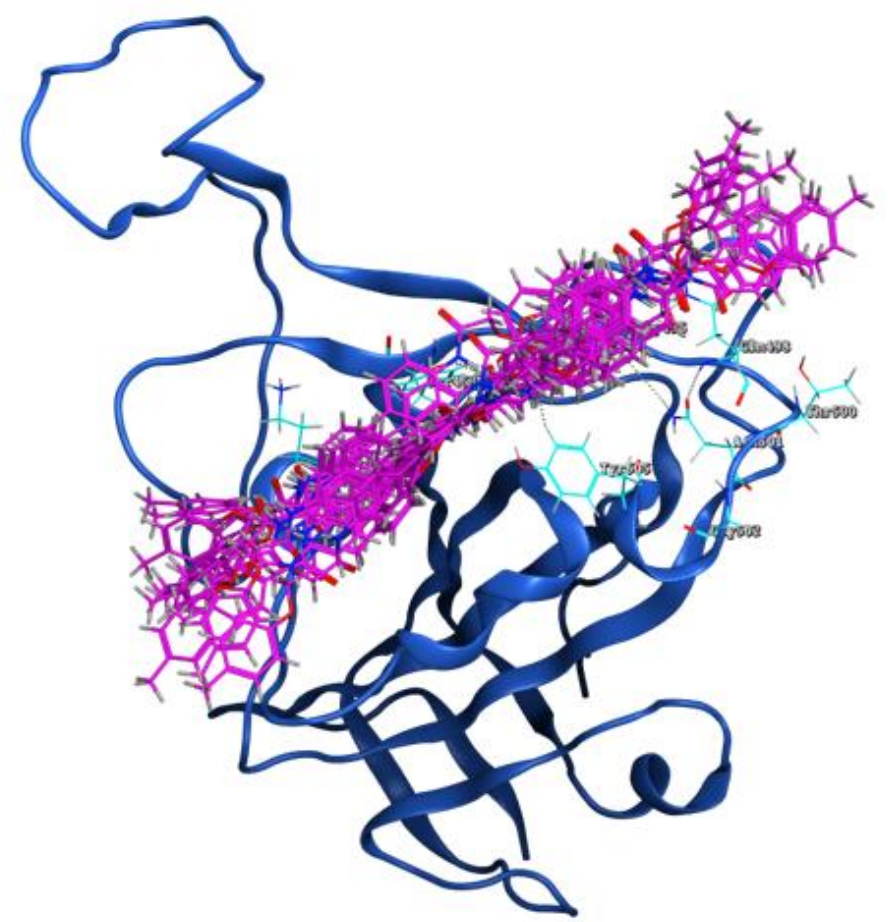

Figure S4. RBD (Blue) shows amino acids Lys417, Tyr453, Gly496, Gln498, Thr500, Gly502, and Tyr505 (Cyan), as region chosen for docking. with 23 conformers of compound R4 (Pink). 


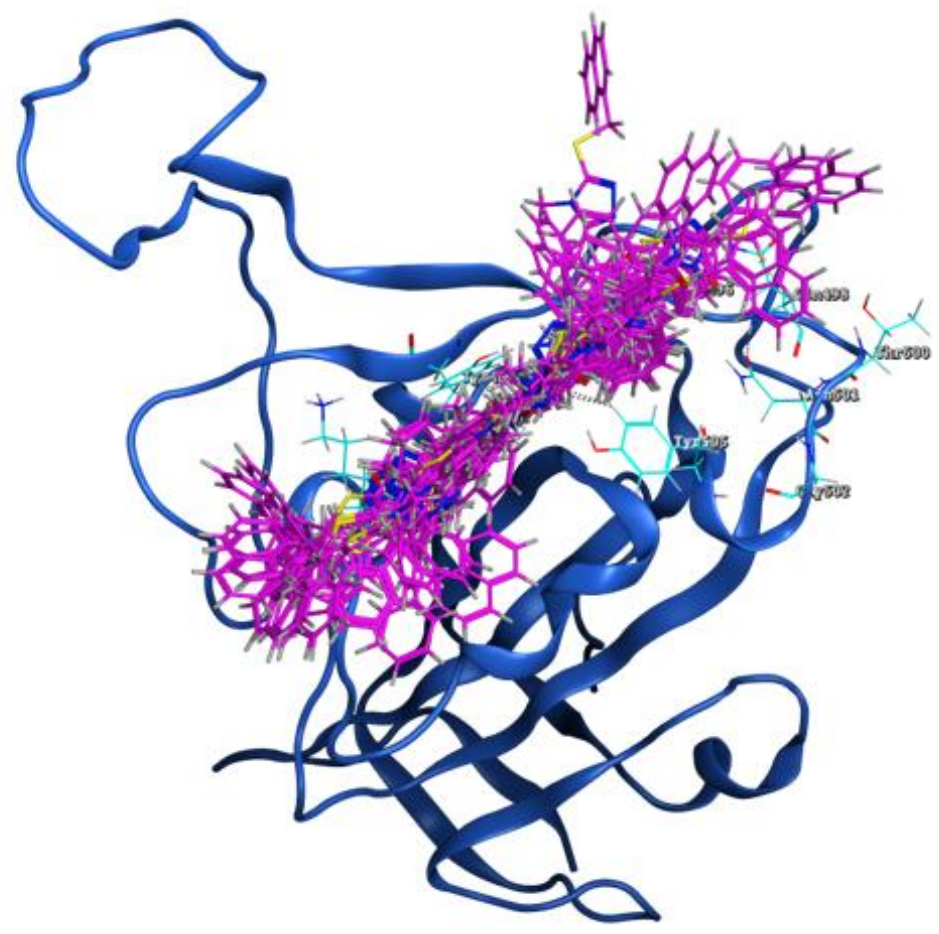

Figure S5. RBD (Blue) shows amino acids Lys417, Tyr453, Gly496, Gln498, Thr500, Gly502, and Tyr505 (Cyan), as region chosen for docking. with 27 conformers of compound R5 (Pink).

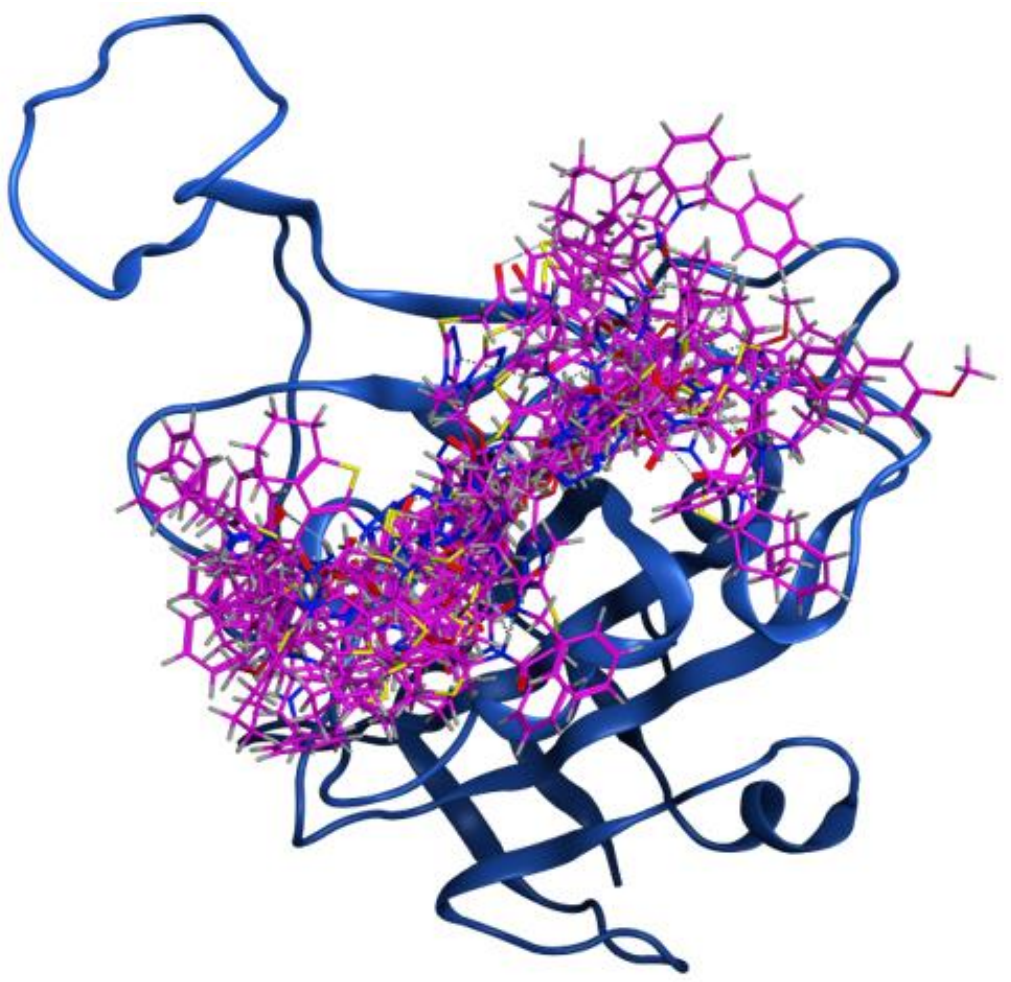

Figure S6. RBD (Blue) shows amino acids Lys417, Tyr453, Gly496, Gln498, Thr500, Gly502, and Tyr505 (Cyan), as region chosen for docking. with 26 conformers of compound R6 (Pink). 


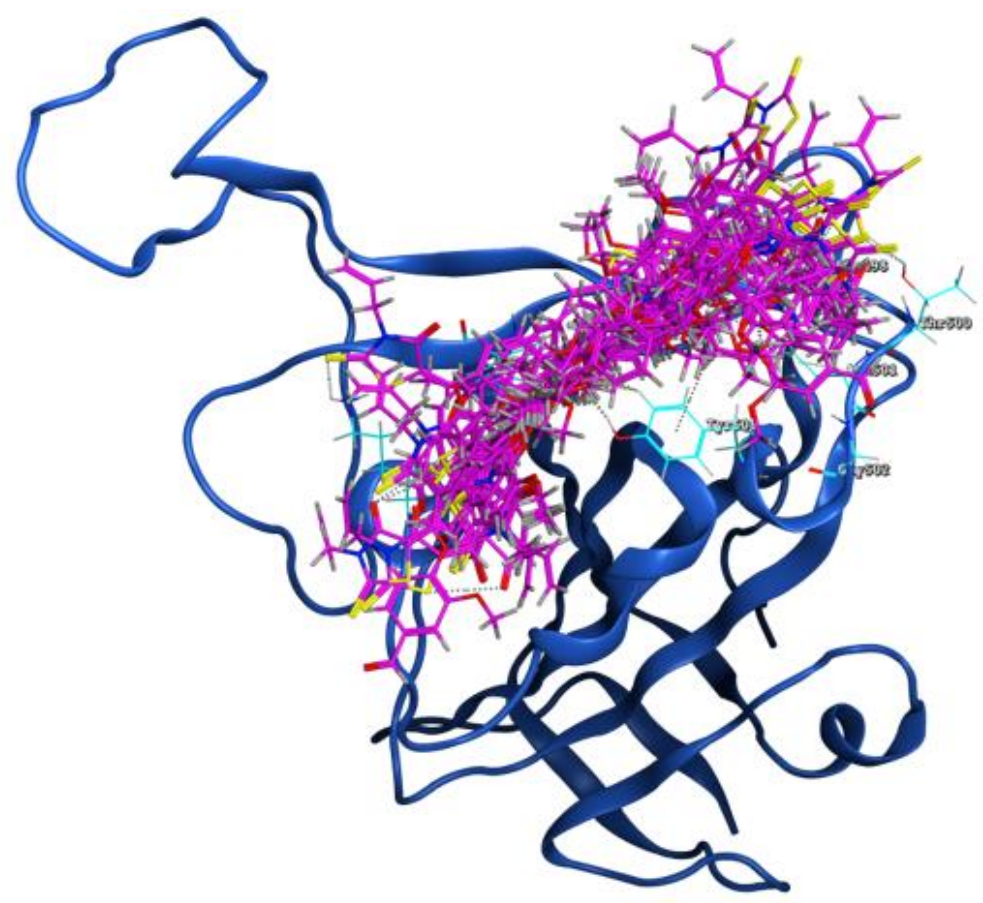

Figure S7. RBD (Blue) shows amino acids Lys417, Tyr453, Gly496, Gln498, Thr500, Gly502, and Tyr505 (Cyan), as region chosen for docking. with 26 conformers of compound R7 (Pink).

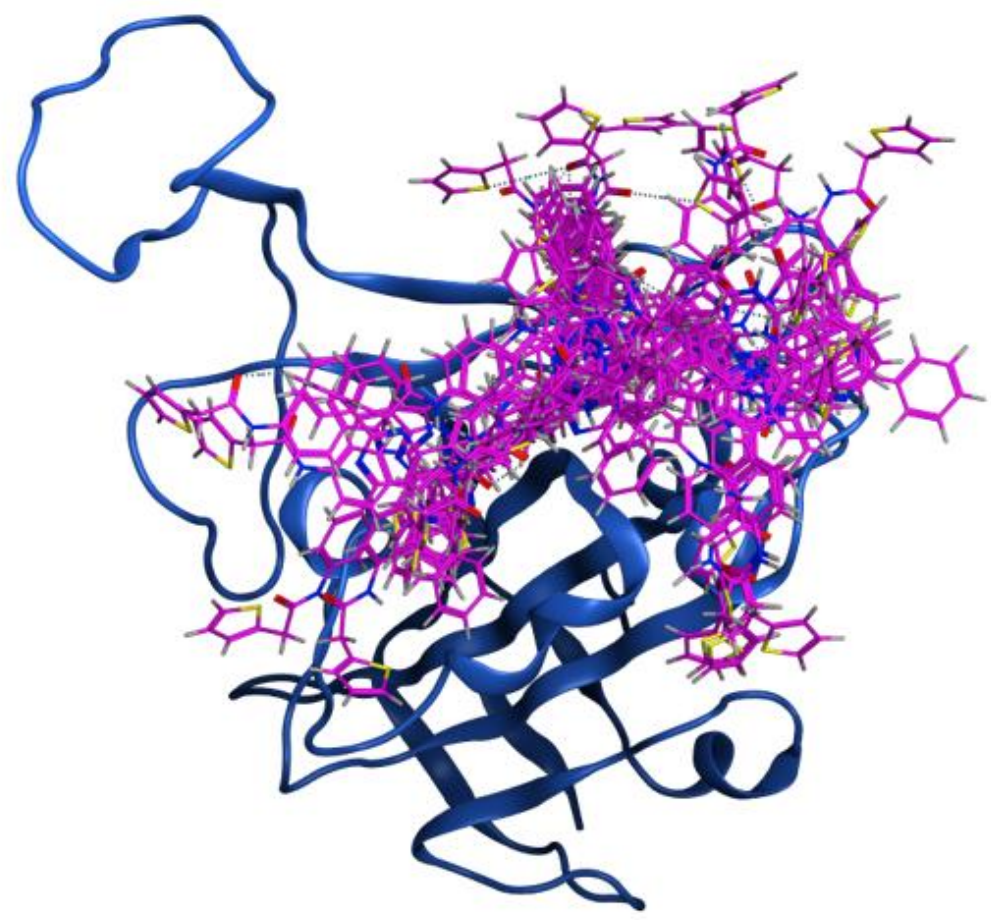

Figure S8. RBD (Blue) shows amino acids Lys417, Tyr453, Gly496, Gln498, Thr500, Gly502, and Tyr505 (Cyan), as region chosen for docking. with 25 conformers of compound R8 (Pink). 


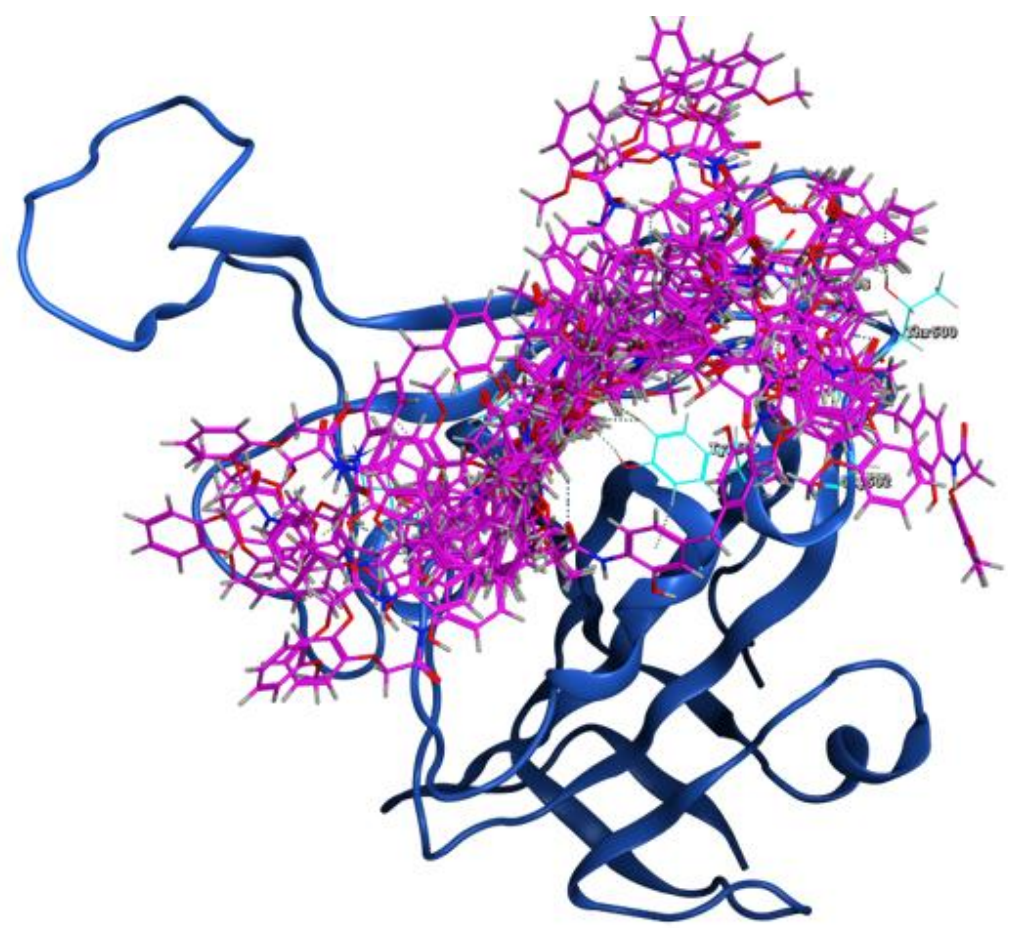

Figure S9. RBD (Blue) shows amino acids Lys417, Tyr453, Gly496, Gln498, Thr500, Gly502, and Tyr505 (Cyan), as region chosen for docking. with 30 conformers of compound R9 (Pink).

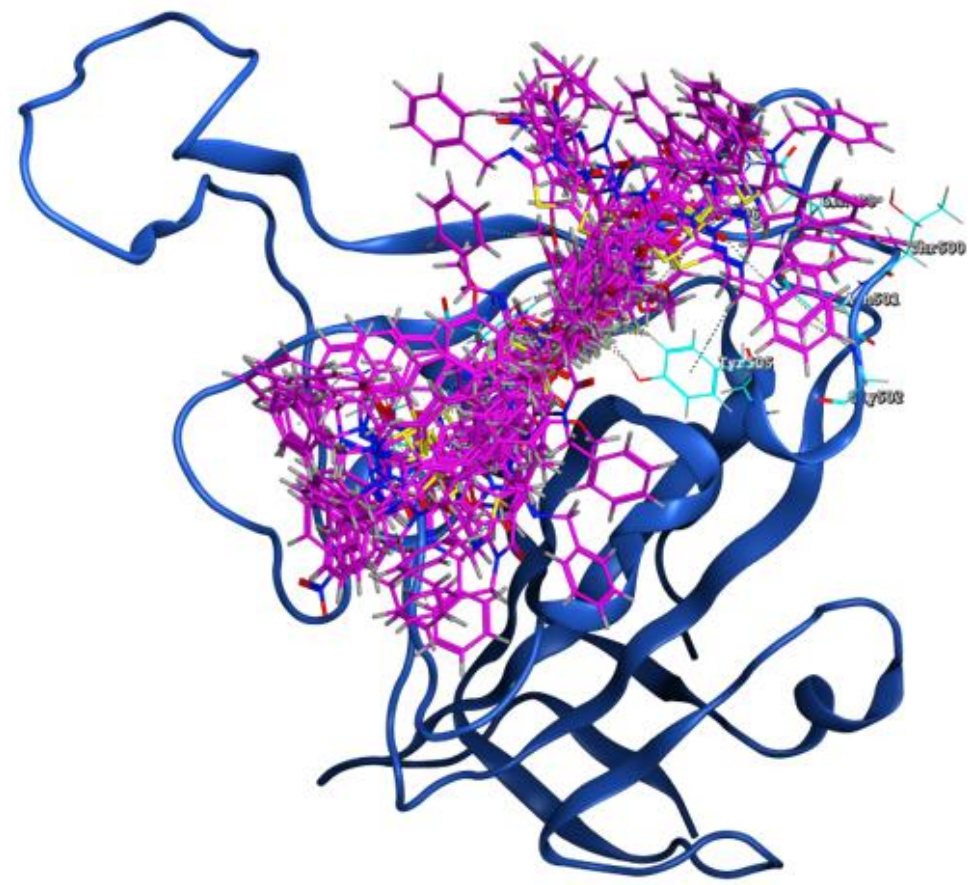

Figure S10. RBD (Blue) shows amino acids Lys417, Tyr453, Gly496, Gln498, Thr500, Gly502, and Tyr505 (Cyan), as region chosen for docking with 26 conformers of compound R10 (Pink).

Table S1. $\Delta \mathrm{G}_{\text {binding }}$ of conformers (23 to 30 conformers) of each compound. Determining the average and SD.

\begin{tabular}{|c|c|c|}
\hline Compound & Conformer & $\Delta$ Gbinding \\
\hline R1 & 1 & -7.2331119 \\
\hline R1 & 2 & -7.2060246 \\
\hline R1 & 3 & -7.0339036 \\
\hline R1 & 4 & -6.8647242 \\
\hline R1 & 5 & -6.7495556 \\
\hline R1 & 6 & -6.7483559 \\
\hline
\end{tabular}




\begin{tabular}{|c|c|c|}
\hline Compound & Conformer & $\Delta$ Gbinding \\
\hline R1 & 7 & -6.6875863 \\
\hline R1 & 8 & -6.4959726 \\
\hline $\mathrm{R} 1$ & 9 & -6.4462318 \\
\hline $\mathrm{R} 1$ & 10 & -6.4292998 \\
\hline R1 & 11 & -6.3906956 \\
\hline $\mathrm{R} 1$ & 12 & -6.3088284 \\
\hline $\mathrm{R} 1$ & 13 & -6.2796907 \\
\hline $\mathrm{R} 1$ & 14 & -6.2491703 \\
\hline $\mathrm{R} 1$ & 15 & -6.158937 \\
\hline $\mathrm{R} 1$ & 16 & -6.109056 \\
\hline $\mathrm{R} 1$ & 17 & -6.0130754 \\
\hline $\mathrm{R} 1$ & 18 & -5.9979191 \\
\hline $\mathrm{R} 1$ & 19 & -5.9444871 \\
\hline $\mathrm{R} 1$ & 20 & -5.857439 \\
\hline $\mathrm{R} 1$ & 21 & -5.6574349 \\
\hline R1 & 22 & -5.3348861 \\
\hline $\mathrm{R} 1$ & 23 & -5.1818366 \\
\hline $\mathrm{R} 1$ & 24 & -5.1590252 \\
\hline \multirow[t]{3}{*}{$\mathrm{R} 1$} & 25 & -4.8872619 \\
\hline & Average $\Delta \mathrm{G}_{\text {binding }}$ & -6.21698038 \\
\hline & SD & \pm 0.62 \\
\hline R2 & 1 & -6.7664809 \\
\hline $\mathrm{R} 2$ & 2 & -6.4214549 \\
\hline $\mathrm{R} 2$ & 3 & -6.3933887 \\
\hline $\mathrm{R} 2$ & 4 & -6.3315854 \\
\hline $\mathrm{R} 2$ & 5 & -6.32091 \\
\hline $\mathrm{R} 2$ & 6 & -6.3154831 \\
\hline $\mathrm{R} 2$ & 7 & -6.314508 \\
\hline $\mathrm{R} 2$ & 8 & -6.2792678 \\
\hline $\mathrm{R} 2$ & 9 & -6.2149229 \\
\hline $\mathrm{R} 2$ & 10 & -6.2144265 \\
\hline R2 & 11 & -6.1770554 \\
\hline $\mathrm{R} 2$ & 12 & -6.1106873 \\
\hline $\mathrm{R} 2$ & 13 & -6.1036081 \\
\hline $\mathrm{R} 2$ & 14 & -6.0555568 \\
\hline $\mathrm{R} 2$ & 15 & -6.0159683 \\
\hline $\mathrm{R} 2$ & 16 & -5.9760051 \\
\hline $\mathrm{R} 2$ & 17 & -5.8339138 \\
\hline $\mathrm{R} 2$ & 18 & -5.8242407 \\
\hline $\mathrm{R} 2$ & 19 & -5.693037 \\
\hline $\mathrm{R} 2$ & 20 & -5.6349249 \\
\hline $\mathrm{R} 2$ & 21 & -5.631999 \\
\hline $\mathrm{R} 2$ & 22 & -5.5930738 \\
\hline $\mathrm{R} 2$ & 23 & -5.5459528 \\
\hline $\mathrm{R} 2$ & 24 & -5.5203071 \\
\hline $\mathrm{R} 2$ & 25 & -5.351244 \\
\hline $\mathrm{R} 2$ & 26 & -5.2036734 \\
\hline $\mathrm{R} 2$ & 27 & -5.1064463 \\
\hline \multirow[t]{3}{*}{$\mathrm{R} 2$} & 28 & -4.791348 \\
\hline & Average $\Delta \mathrm{G}_{\text {binding }}$ & -5.91933821 \\
\hline & SD & \pm 0.46 \\
\hline R3 & 1 & -6.9838405 \\
\hline R3 & 2 & -6.8462219 \\
\hline R3 & 3 & -6.8056817 \\
\hline R3 & 4 & -6.5285497 \\
\hline $\mathrm{R} 3$ & 5 & -6.1570921 \\
\hline
\end{tabular}




\begin{tabular}{|c|c|c|}
\hline Compound & Conformer & $\Delta$ Gbinding \\
\hline R3 & 6 & -6.1317654 \\
\hline R3 & 7 & -6.1204648 \\
\hline R3 & 8 & -6.0225105 \\
\hline R3 & 9 & -6.0142112 \\
\hline R3 & 10 & -5.9668207 \\
\hline R3 & 11 & -5.9426217 \\
\hline R3 & 12 & -5.9286957 \\
\hline $\mathrm{R} 3$ & 13 & -5.9193277 \\
\hline R3 & 14 & -5.880055 \\
\hline $\mathrm{R} 3$ & 15 & -5.712388 \\
\hline $\mathrm{R} 3$ & 16 & -5.6240087 \\
\hline R3 & 17 & -5.5277014 \\
\hline R3 & 18 & -5.5202971 \\
\hline R3 & 19 & -5.4840665 \\
\hline R3 & 20 & -5.4422593 \\
\hline R3 & 21 & -5.1444192 \\
\hline R3 & 22 & -4.9145379 \\
\hline \multirow[t]{3}{*}{$\mathrm{R} 3$} & 23 & -4.7276583 \\
\hline & Average $\Delta G_{\text {binding }}$ & -5.8845737 \\
\hline & SD & \pm 0.57 \\
\hline R4 & 1 & -6.7632031 \\
\hline $\mathrm{R} 4$ & 2 & -6.4043522 \\
\hline $\mathrm{R} 4$ & 3 & -6.2631483 \\
\hline $\mathrm{R} 4$ & 4 & -6.2200856 \\
\hline $\mathrm{R} 4$ & 5 & -6.1751533 \\
\hline R4 & 6 & -6.1260304 \\
\hline $\mathrm{R} 4$ & 7 & -6.1187668 \\
\hline $\mathrm{R} 4$ & 8 & -6.0734396 \\
\hline $\mathrm{R} 4$ & 9 & -5.996778 \\
\hline $\mathrm{R} 4$ & 10 & -5.9447236 \\
\hline $\mathrm{R} 4$ & 11 & -5.9102702 \\
\hline $\mathrm{R} 4$ & 12 & -5.8583083 \\
\hline $\mathrm{R} 4$ & 13 & -5.8441443 \\
\hline $\mathrm{R} 4$ & 14 & -5.8113565 \\
\hline $\mathrm{R} 4$ & 15 & -5.7965097 \\
\hline $\mathrm{R} 4$ & 16 & -5.6938453 \\
\hline $\mathrm{R} 4$ & 17 & -5.5749726 \\
\hline $\mathrm{R} 4$ & 18 & -5.5663042 \\
\hline $\mathrm{R} 4$ & 19 & -5.5587106 \\
\hline $\mathrm{R} 4$ & 20 & -5.5300426 \\
\hline $\mathrm{R} 4$ & 21 & -5.5095415 \\
\hline $\mathrm{R} 4$ & 22 & -5.1574287 \\
\hline \multirow[t]{3}{*}{$\mathrm{R} 4$} & 23 & -4.55792 \\
\hline & Average $\Delta \mathrm{G}_{\text {binding }}$ & -5.8458711 \\
\hline & SD & \pm 0.44 \\
\hline R5 & 1 & -7.0540476 \\
\hline R5 & 2 & -6.9974627 \\
\hline R5 & 3 & -6.7864766 \\
\hline R5 & 4 & -6.5201869 \\
\hline R5 & 5 & -6.3118415 \\
\hline R5 & 6 & -6.1991568 \\
\hline $\mathrm{R} 5$ & 7 & -6.1128678 \\
\hline R5 & 8 & -5.9717464 \\
\hline R5 & 9 & -5.9277887 \\
\hline R5 & 10 & -5.9091444 \\
\hline R5 & 11 & -5.8888454 \\
\hline
\end{tabular}




\begin{tabular}{|c|c|c|}
\hline Compound & Conformer & $\Delta$ Gbinding \\
\hline R5 & 12 & -5.7561822 \\
\hline R5 & 13 & -5.7483029 \\
\hline R5 & 14 & -5.7370377 \\
\hline R5 & 15 & -5.7046599 \\
\hline R5 & 16 & -5.609766 \\
\hline R5 & 17 & -5.609632 \\
\hline R5 & 18 & -5.5986104 \\
\hline R5 & 19 & -5.5095038 \\
\hline R5 & 20 & -5.4846411 \\
\hline R5 & 21 & -5.4378185 \\
\hline R5 & 22 & -5.4288836 \\
\hline R5 & 23 & -5.4227753 \\
\hline R5 & 24 & -5.2630024 \\
\hline R5 & 25 & -5.2263398 \\
\hline R5 & 26 & -5.1524119 \\
\hline \multirow[t]{3}{*}{ R5 } & 27 & -5.1467886 \\
\hline & Average $\Delta G_{\text {binding }}$ & -5.833923 \\
\hline & SD & \pm 0.52 \\
\hline R6 & 1 & -6.6316271 \\
\hline R6 & 2 & -6.531496 \\
\hline R6 & 3 & -6.3979082 \\
\hline R6 & 4 & -6.3553157 \\
\hline R6 & 5 & -6.1730232 \\
\hline R6 & 6 & -6.1443419 \\
\hline R6 & 7 & -6.0652223 \\
\hline R6 & 8 & -6.0623302 \\
\hline R6 & 9 & -6.0476213 \\
\hline R6 & 10 & -6.013927 \\
\hline R6 & 11 & -5.9997869 \\
\hline R6 & 12 & -5.9780679 \\
\hline R6 & 13 & -5.9647527 \\
\hline R6 & 14 & -5.9493237 \\
\hline R6 & 15 & -5.9476452 \\
\hline R6 & 16 & -5.8769274 \\
\hline R6 & 17 & -5.7677441 \\
\hline R6 & 18 & -5.7652736 \\
\hline R6 & 19 & -5.6708832 \\
\hline R6 & 20 & -5.6249809 \\
\hline R6 & 21 & -5.6151843 \\
\hline R6 & 22 & -5.5595589 \\
\hline R6 & 23 & -5.4790697 \\
\hline R6 & 24 & -5.4070182 \\
\hline R6 & 25 & -5.3746576 \\
\hline R6 & 26 & -5.0022559 \\
\hline R6 & 27 & -5.0015974 \\
\hline \multirow[t]{3}{*}{ R6 } & 28 & -4.9277129 \\
\hline & Average $\Delta \mathrm{G}_{\text {binding }}$ & -5.83340191 \\
\hline & SD & 0.43583264 \\
\hline R7 & 1 & -6.8522887 \\
\hline R7 & 2 & -6.5122266 \\
\hline R7 & 3 & -6.4491115 \\
\hline R7 & 4 & -6.4435782 \\
\hline R7 & 5 & -6.4315424 \\
\hline R7 & 6 & -6.1583447 \\
\hline R7 & 7 & -6.0595407 \\
\hline R7 & 8 & -6.0270767 \\
\hline
\end{tabular}




\begin{tabular}{|c|c|c|}
\hline Compound & Conformer & $\Delta$ Gbinding \\
\hline R7 & 9 & -6.0180469 \\
\hline R7 & 10 & -6.0068564 \\
\hline R7 & 11 & -5.9803696 \\
\hline $\mathrm{R} 7$ & 12 & -5.8949351 \\
\hline R7 & 13 & -5.8882146 \\
\hline R7 & 14 & -5.8428049 \\
\hline R7 & 15 & -5.8407564 \\
\hline R7 & 16 & -5.8271775 \\
\hline R7 & 17 & -5.745029 \\
\hline R7 & 18 & -5.5404458 \\
\hline R7 & 19 & -5.5223618 \\
\hline R7 & 20 & -5.4813976 \\
\hline R7 & 21 & -5.4163742 \\
\hline R7 & 22 & -5.3106384 \\
\hline R7 & 23 & -5.2996225 \\
\hline R7 & 24 & -5.2951803 \\
\hline R7 & 25 & -5.1050701 \\
\hline \multirow[t]{3}{*}{ R7 } & 26 & -4.701251 \\
\hline & Average $\Delta \mathrm{G}_{\text {binding }}$ & -5.8327016 \\
\hline & SD & \pm 0.6249 \\
\hline R8 & 1 & -6.7326531 \\
\hline R8 & 2 & -6.5280132 \\
\hline $\mathrm{R} 8$ & 3 & -6.523767 \\
\hline R8 & 4 & -6.503541 \\
\hline $\mathrm{R} 8$ & 5 & -6.0592937 \\
\hline R8 & 6 & -6.0208974 \\
\hline R8 & 7 & -6.0082111 \\
\hline R8 & 8 & -5.9772091 \\
\hline R8 & 9 & -5.8727155 \\
\hline R8 & 10 & -5.8443942 \\
\hline $\mathrm{R} 8$ & 11 & -5.8211112 \\
\hline $\mathrm{R} 8$ & 12 & -5.817112 \\
\hline $\mathrm{R} 8$ & 13 & -5.7668514 \\
\hline $\mathrm{R} 8$ & 14 & -5.7560153 \\
\hline $\mathrm{R} 8$ & 15 & -5.7452903 \\
\hline $\mathrm{R} 8$ & 16 & -5.6895194 \\
\hline $\mathrm{R} 8$ & 17 & -5.680151 \\
\hline $\mathrm{R} 8$ & 18 & -5.6375241 \\
\hline $\mathrm{R} 8$ & 19 & -5.6060319 \\
\hline $\mathrm{R} 8$ & 20 & -5.5317001 \\
\hline $\mathrm{R} 8$ & 21 & -5.5244312 \\
\hline $\mathrm{R} 8$ & 22 & -5.4838753 \\
\hline $\mathrm{R} 8$ & 23 & -5.3497686 \\
\hline R8 & 24 & -5.0877872 \\
\hline \multirow[t]{3}{*}{$\mathrm{R} 8$} & 25 & -5.0507255 \\
\hline & Average $\Delta \mathrm{G}_{\text {binding }}$ & -5.82474359 \\
\hline & SD & 0.41922409 \\
\hline R9 & 1 & -6.6013284 \\
\hline R9 & 2 & -6.6013021 \\
\hline R9 & 3 & -6.54562 \\
\hline R9 & 4 & -6.3383489 \\
\hline R9 & 5 & -6.3168378 \\
\hline R9 & 6 & -6.3073845 \\
\hline R9 & 7 & -6.272552 \\
\hline R9 & 8 & -6.1454167 \\
\hline R9 & 9 & -6.1359248 \\
\hline
\end{tabular}




\begin{tabular}{|c|c|c|}
\hline Compound & Conformer & $\Delta$ Gbinding \\
\hline R9 & 10 & -6.1313753 \\
\hline R9 & 11 & -6.0432882 \\
\hline R9 & 12 & -5.9264412 \\
\hline R9 & 13 & -5.9164457 \\
\hline R9 & 14 & -5.8949504 \\
\hline R9 & 15 & -5.8537846 \\
\hline R9 & 16 & -5.8511791 \\
\hline R9 & 17 & -5.8180528 \\
\hline R9 & 18 & -5.7812982 \\
\hline R9 & 19 & -5.758338 \\
\hline R9 & 20 & -5.73105 \\
\hline R9 & 21 & -5.702023 \\
\hline R9 & 22 & -5.6906929 \\
\hline R9 & 23 & -5.6595364 \\
\hline R9 & 24 & -5.5401473 \\
\hline R9 & 25 & -5.5328937 \\
\hline R9 & 26 & -5.512238 \\
\hline R9 & 27 & -5.3337536 \\
\hline R9 & 28 & -5.0034127 \\
\hline R9 & 29 & -4.8866568 \\
\hline \multirow[t]{3}{*}{ R9 } & 30 & -3.7863204 \\
\hline & Average $\Delta \mathrm{G}_{\text {binding }}$ & -5.82061978 \\
\hline & SD & \pm 0.56 \\
\hline R10 & 1 & -6.7684965 \\
\hline $\mathrm{R} 10$ & 2 & -6.7468953 \\
\hline $\mathrm{R} 10$ & 3 & -6.6069436 \\
\hline $\mathrm{R} 10$ & 4 & -6.3902907 \\
\hline R10 & 5 & -6.3285928 \\
\hline R10 & 6 & -6.0805092 \\
\hline $\mathrm{R} 10$ & 7 & -6.0715919 \\
\hline R10 & 8 & -6.0187011 \\
\hline R10 & 9 & -5.9624271 \\
\hline $\mathrm{R} 10$ & 10 & -5.8690481 \\
\hline R10 & 11 & -5.8441906 \\
\hline $\mathrm{R} 10$ & 12 & -5.8227491 \\
\hline $\mathrm{R} 10$ & 13 & -5.8006115 \\
\hline $\mathrm{R} 10$ & 14 & -5.7594738 \\
\hline $\mathrm{R} 10$ & 15 & -5.7442722 \\
\hline $\mathrm{R} 10$ & 16 & -5.7260971 \\
\hline $\mathrm{R} 10$ & 17 & -5.7088141 \\
\hline $\mathrm{R} 10$ & 18 & -5.6658616 \\
\hline $\mathrm{R} 10$ & 19 & -5.5842304 \\
\hline $\mathrm{R} 10$ & 20 & -5.5423489 \\
\hline R10 & 21 & -5.4113111 \\
\hline R10 & 22 & -5.2722654 \\
\hline R10 & 23 & -5.197022 \\
\hline $\mathrm{R} 10$ & 24 & -5.1839638 \\
\hline R10 & 25 & -5.1252923 \\
\hline R10 & 26 & -5.0220327 \\
\hline \multirow[t]{2}{*}{ R10 } & Average $\Delta \mathrm{G}_{\text {binding }}$ & -5.8174628 \\
\hline & SD & \pm 0.47 \\
\hline
\end{tabular}

Table S2. Interaction report of each conformer of compound R1. Number of conformer, Atom of compound, Residue in RBD, Type of interaction and Distance in angstroms.

\begin{tabular}{|c|l|c|c|c|c|}
\hline Conformer & Ligand & \multicolumn{2}{|c|}{ Residues in RBD } & Interaction & Distance \\
\hline 1 & O & LYS & 417 & H-acceptor & 3.12 \\
\hline 2 & O & LYS & 417 & H-acceptor & 3.12 \\
\hline
\end{tabular}




\begin{tabular}{|c|c|c|c|c|c|}
\hline 3 & $\mathrm{~N}$ & GLU & 406 & H-donor & 3.34 \\
\hline 4 & $\mathrm{O}$ & LYS & 417 & H-acceptor & 3.07 \\
\hline \multirow[t]{2}{*}{5} & $\mathrm{O}$ & LYS & 417 & H-acceptor & 3.11 \\
\hline & 6-ring & GLY & 416 & pi-H & 4.01 \\
\hline 6 & 6-ring & GLY & 496 & pi-H & 3.63 \\
\hline \multirow[t]{3}{*}{7} & $\mathrm{~N}$ & GLU & 406 & H-donor & 3.36 \\
\hline & 6-ring & TYR & 505 & pi-H & 4.37 \\
\hline & 6-ring & TYR & 505 & pi-H & 4.45 \\
\hline \multirow[t]{3}{*}{8} & $\mathrm{~N}$ & GLU & 406 & H-donor & 3.36 \\
\hline & 6-ring & TYR & 505 & pi-H & 4.52 \\
\hline & 6-ring & TYR & 505 & pi-H & 4.38 \\
\hline \multirow[t]{2}{*}{9} & $\mathrm{O}$ & LYS & 417 & H-acceptor & 3.34 \\
\hline & 6-ring & GLY & 416 & pi-H & 4 \\
\hline 10 & $\mathrm{~N}$ & GLU & 406 & H-donor & 3.39 \\
\hline 11 & 6-ring & TYR & 505 & pi-H & 3.98 \\
\hline 12 & 6-ring & GLN & 498 & pi-H & 3.96 \\
\hline 13 & 6-ring & GLY & 496 & pi-H & 3.82 \\
\hline 14 & 6-ring & GLN & 498 & pi-H & 3.91 \\
\hline \multirow[t]{2}{*}{15} & 6-ring & GLN & 498 & pi-H & 3.85 \\
\hline & 6-ring & TYR & 505 & pi-H & 3.74 \\
\hline \multirow[t]{2}{*}{16} & 6-ring & TYR & 505 & pi-H & 4.01 \\
\hline & 6-ring & TYR & 505 & pi-H & 4.41 \\
\hline 17 & 6-ring & GLY & 416 & pi-H & 4.1 \\
\hline 18 & $\mathrm{O}$ & TYR & 505 & H-acceptor & 3.32 \\
\hline \multirow[t]{2}{*}{19} & $\mathrm{O}$ & ARG & 403 & H-acceptor & 3.08 \\
\hline & 6-ring & TYR & 505 & pi-H & 4.02 \\
\hline 20 & $\mathrm{O}$ & TYR & 449 & H-acceptor & 3 \\
\hline
\end{tabular}

Table S3. Interaction report of each conformer of compound R2. Number of conformer, Atom of compound, Residue in RBD, Type of interaction and Distance in angstroms.

\begin{tabular}{|c|c|c|c|c|c|}
\hline \multirow{2}{*}{$\begin{array}{c}\text { Conformer } \\
1\end{array}$} & \multirow{2}{*}{$\begin{array}{l}\text { Ligand } \\
\text { 6-ring }\end{array}$} & \multicolumn{2}{|c|}{ Residues in RBD } & \multirow{2}{*}{$\begin{array}{c}\text { Interaction } \\
\text { pi-H }\end{array}$} & \multirow{2}{*}{$\begin{array}{c}\text { Distance } \\
3.97\end{array}$} \\
\hline & & LYS & 417 & & \\
\hline \multirow[t]{3}{*}{2} & $\mathrm{O}$ & TYR & 453 & H-acceptor & 2.87 \\
\hline & 6-ring & TYR & 449 & pi-H & 3.57 \\
\hline & 6-ring & GLY & 496 & pi-H & 3.79 \\
\hline 3 & 6-ring & PHE & 456 & pi-H & 4.09 \\
\hline 4 & 6-ring & GLY & 502 & pi-H & 4.1 \\
\hline 5 & 6-ring & GLY & 496 & pi-H & 4.57 \\
\hline \multirow[t]{2}{*}{6} & $\mathrm{O}$ & TYR & 453 & H-acceptor & 2.88 \\
\hline & 6-ring & TYR & 449 & pi-H & 3.61 \\
\hline 7 & 6-ring & TYR & 449 & pi-H & 4.63 \\
\hline \multirow[t]{3}{*}{8} & $\mathrm{O}$ & GLY & 502 & H-acceptor & 3.03 \\
\hline & 6-ring & GLY & 496 & pi-H & 3.84 \\
\hline & 6-ring & TYR & 505 & pi-H & 3.88 \\
\hline \multirow[t]{3}{*}{9} & $\mathrm{O}$ & TYR & 449 & H-acceptor & 2.79 \\
\hline & 6-ring & TYR & 453 & pi-H & 3.42 \\
\hline & 6-ring & GLN & 498 & pi-H & 4.67 \\
\hline \multirow[t]{2}{*}{10} & 6-ring & TYR & 495 & pi-H & 4.83 \\
\hline & 6-ring & THR & 500 & pi-H & 3.95 \\
\hline 11 & $\mathrm{~N}$ & GLN & 493 & H-acceptor & 3.29 \\
\hline 12 & 6-ring & PHE & 456 & pi-H & 4.16 \\
\hline \multirow[t]{2}{*}{13} & 6-ring & GLY & 496 & pi-H & 3.67 \\
\hline & 6-ring & GLN & 498 & pi-H & 4.3 \\
\hline 14 & 6-ring & GLY & 496 & pi-H & 3.77 \\
\hline 15 & 6-ring & TYR & 495 & pi-H & 4.85 \\
\hline \multirow[t]{3}{*}{16} & 6-ring & GLY & 502 & pi-H & 4.05 \\
\hline & 6-ring & TYR & 505 & pi-H & 3.87 \\
\hline & 6-ring & TYR & 505 & pi-pi & 3.9 \\
\hline
\end{tabular}




\begin{tabular}{|c|l|l|c|c|c|}
\hline Conformer & Ligand & \multicolumn{2}{|c|}{ Residues in RBD } & Interaction & Distance \\
\hline 17 & 6-ring & TYR & 449 & pi-H & 3.8 \\
\hline & 6-ring & LEU & 455 & pi-H & 4.1 \\
\hline 18 & O & GLY & 496 & H-acceptor & 3.24 \\
\hline 19 & N & GLY & 502 & H-acceptor & 3.14 \\
\hline & 6-ring & GLN & 498 & pi-H & 4.02 \\
\hline 20 & 6-ring & GLN & 493 & pi-H & 3.79 \\
\hline & 6-ring & TYR & 495 & pi-H & 4.77 \\
\hline
\end{tabular}

Table S4. Interaction report of each conformer of compound R3. Number of conformer, Atom of compound, Residue in RBD, Type of interaction and Distance in angstroms.

\begin{tabular}{|c|c|c|c|c|c|}
\hline \multirow{2}{*}{$\begin{array}{c}\text { Conformer } \\
1\end{array}$} & \multirow{2}{*}{$\begin{array}{l}\text { Ligand } \\
\mathrm{O}\end{array}$} & \multicolumn{2}{|c|}{ Residues in RBD } & \multirow{2}{*}{$\begin{array}{c}\text { Interaction } \\
\mathrm{H} \text {-acceptor }\end{array}$} & \multirow{2}{*}{$\begin{array}{c}\text { Distance } \\
3.16\end{array}$} \\
\hline & & LYS & 417 & & \\
\hline \multirow[t]{3}{*}{2} & $\mathrm{O}$ & GLN & 493 & H-acceptor & 3.29 \\
\hline & $\mathrm{O}$ & LYS & 417 & H-acceptor & 3.4 \\
\hline & 6-ring & GLY & 496 & pi-H & 3.83 \\
\hline 3 & 6-ring & LYS & 417 & pi-H & 4.16 \\
\hline \multirow[t]{2}{*}{4} & 6-ring & LYS & 417 & pi-H & 4.29 \\
\hline & 6-ring & GLY & 496 & pi-H & 3.75 \\
\hline 5 & $\mathrm{O}$ & ARG & 403 & H-acceptor & 2.97 \\
\hline 6 & $\mathrm{O}$ & ARG & 403 & $\mathrm{H}$-acceptor & 3.09 \\
\hline \multirow[t]{2}{*}{7} & $\mathrm{O}$ & ARG & 403 & H-acceptor & 3.05 \\
\hline & 6-ring & GLY & 416 & pi-H & 4.17 \\
\hline \multirow[t]{3}{*}{9} & $\mathrm{O}$ & LYS & 417 & H-acceptor & 2.93 \\
\hline & $\mathrm{O}$ & ARG & 403 & H-acceptor & 2.91 \\
\hline & 6-ring & TYR & 495 & pi-H & 4.78 \\
\hline 10 & $\mathrm{O}$ & ARG & 403 & H-acceptor & 3.12 \\
\hline 11 & $\mathrm{O}$ & LYS & 417 & H-acceptor & 3.18 \\
\hline \multirow[t]{2}{*}{12} & $\mathrm{O}$ & ARG & 403 & H-acceptor & 2.94 \\
\hline & 6-ring & TYR & 495 & pi-H & 4.78 \\
\hline 13 & $\mathrm{O}$ & ARG & 408 & H-acceptor & 2.87 \\
\hline 14 & $\mathrm{O}$ & ARG & 403 & H-acceptor & 2.89 \\
\hline 15 & $\mathrm{O}$ & LYS & 417 & $\mathrm{H}$-acceptor & 3.22 \\
\hline 16 & 6-ring & GLY & 502 & pi-H & 4.93 \\
\hline 17 & $\mathrm{O}$ & LYS & 417 & H-acceptor & 3.16 \\
\hline \multirow[t]{3}{*}{18} & $\mathrm{O}$ & ARG & 408 & $\mathrm{H}$-acceptor & 3.14 \\
\hline & $\mathrm{O}$ & ARG & 408 & H-acceptor & 3.41 \\
\hline & 6-ring & ARG & 403 & pi-cation & 3.95 \\
\hline
\end{tabular}

Table S5. Interaction report of each conformer of compound R4. Number of conformer, Atom of compound, Residue in RBD, Type of interaction and Distance in angstroms.

\begin{tabular}{|c|c|c|c|c|c|}
\hline Conformer & Ligand & \multicolumn{2}{|c|}{ Residues in RBD } & Interaction & Distance \\
\hline \multirow[t]{3}{*}{1} & 6-ring & THR & 415 & $\mathrm{pi}-\mathrm{H}$ & 3.86 \\
\hline & 6-ring & LYS & 417 & pi-H & 4.39 \\
\hline & 6-ring & GLY & 496 & pi-H & 4.07 \\
\hline \multirow[t]{3}{*}{2} & 6-ring & THR & 415 & $\mathrm{pi}-\mathrm{H}$ & 3.86 \\
\hline & 6-ring & LYS & 417 & $\mathrm{pi}-\mathrm{H}$ & 4.84 \\
\hline & 6-ring & GLY & 496 & pi-H & 3.86 \\
\hline 3 & $\mathrm{O}$ & TYR & 449 & H-acceptor & 2.96 \\
\hline 4 & 6-ring & LYS & 417 & pi-H & 4.24 \\
\hline \multirow[t]{3}{*}{5} & $\mathrm{~N}$ & GLU & 406 & H-donor & 3.41 \\
\hline & 6-ring & LYS & 417 & pi-H & 4.21 \\
\hline & 6-ring & GLY & 496 & pi-H & 4.41 \\
\hline 6 & 6-ring & GLY & 496 & $\mathrm{pi}-\mathrm{H}$ & 3.92 \\
\hline
\end{tabular}




\begin{tabular}{|c|l|l|l|c|c|}
\hline Conformer & Ligand & \multicolumn{2}{|c|}{ Residues in RBD } & Interaction & Distance \\
\hline 7 & 6-ring & GLY & 446 & pi-H & 3.93 \\
\hline 8 & O & LYS & 417 & H-acceptor & 3.37 \\
\hline & 6-ring & GLY & 496 & pi-H & 3.92 \\
\hline 9 & 6-ring & THR & 415 & pi-H & 3.92 \\
\hline 10 & 0 & TYR & 453 & H-acceptor & 3.04 \\
\hline 11 & 0 & LYS & 417 & H-acceptor & 3.23 \\
\hline & 6-ring & GLY & 496 & pi-H & 4.04 \\
\hline 12 & 6-ring & GLY & 446 & pi-H & 3.84 \\
\hline 13 & 6-ring & GLY & 496 & pi-H & 4 \\
\hline 14 & O & LYS & 417 & H-acceptor & 3.33 \\
\hline 15 & O & TYR & 453 & H-acceptor & 3.12 \\
\hline & 6-ring & ARG & 403 & pi-cation & 3.77 \\
\hline & 6-ring & THR & 415 & pi-H & 4.01 \\
\hline
\end{tabular}

Table S6. Interaction report of each conformer of compound R5. Number of conformer, Atom of compound, Residue in RBD, Type of interaction and Distance in angstroms.

\begin{tabular}{|c|c|c|c|c|c|}
\hline \multirow{2}{*}{$\begin{array}{c}\text { Conformer } \\
1\end{array}$} & \multirow{2}{*}{$\begin{array}{l}\text { Ligand } \\
\mathrm{N}\end{array}$} & \multicolumn{2}{|c|}{ Residues in RBD } & \multirow{2}{*}{$\begin{array}{r}\text { Interaction } \\
\text { H-donor }\end{array}$} & \multirow{2}{*}{$\begin{array}{c}\text { Distance } \\
3.43\end{array}$} \\
\hline & & GLU & 406 & & \\
\hline & 6-ring & GLY & 496 & pi-H & 3.71 \\
\hline \multirow[t]{2}{*}{2} & $\mathrm{~N}$ & GLU & 406 & H-donor & 3.36 \\
\hline & 6-ring & GLY & 496 & pi-H & 3.78 \\
\hline \multirow[t]{2}{*}{3} & $\mathrm{~N}$ & GLU & 406 & H-donor & 3.39 \\
\hline & 6-ring & GLY & 496 & pi-H & 3.73 \\
\hline \multirow[t]{2}{*}{4} & $\mathrm{~N}$ & GLU & 406 & H-donor & 3.32 \\
\hline & $\mathrm{N}$ & LYS & 417 & H-donor & 3.08 \\
\hline 5 & 5-ring & LYS & 417 & pi-H & 3.78 \\
\hline \multirow[t]{2}{*}{6} & 5-ring & LYS & 417 & pi-H & 3.85 \\
\hline & 6-ring & GLY & 496 & pi-H & 3.95 \\
\hline \multirow[t]{2}{*}{7} & 6-ring & LYS & 417 & pi-H & 4.4 \\
\hline & 6-ring & GLN & 498 & pi-H & 3.89 \\
\hline 8 & 6-ring & GLY & 416 & pi-H & 4.32 \\
\hline \multirow[t]{2}{*}{9} & 5-ring & ARG & 403 & pi-cation & 4.14 \\
\hline & 6-ring & ARG & 408 & pi-cation & 3.77 \\
\hline 10 & 6-ring & GLY & 496 & pi-H & 3.64 \\
\hline 11 & 6-ring & ARG & 403 & pi-cation & 3.48 \\
\hline 12 & 6-ring & GLY & 416 & pi-H & 3.98 \\
\hline \multirow[t]{2}{*}{13} & $\mathrm{O}$ & LYS & 417 & H-acceptor & 3.24 \\
\hline & 6-ring & GLY & 496 & pi-H & 3.62 \\
\hline 14 & 6-ring & GLY & 496 & pi-H & 4 \\
\hline 15 & $\mathrm{~N}$ & GLY & 496 & H-donor & 3.27 \\
\hline 16 & $\mathrm{O}$ & GLY & 496 & H-acceptor & 3.54 \\
\hline 17 & 6-ring & GLY & 416 & pi-H & 3.89 \\
\hline 18 & 6-ring & GLY & 496 & pi-H & 3.67 \\
\hline 19 & $\mathrm{O}$ & GLY & 496 & H-acceptor & 3.51 \\
\hline 20 & 6-ring & GLY & 446 & pi-H & 4.61 \\
\hline \multirow[t]{2}{*}{21} & $\mathrm{O}$ & LYS & 417 & H-acceptor & 3.09 \\
\hline & 6-ring & GLY & 496 & pi-H & 3.68 \\
\hline 22 & 6-ring & ARG & 403 & pi-cation & 3.55 \\
\hline \multirow[t]{2}{*}{23} & 6-ring & ARG & 403 & pi-cation & 3.63 \\
\hline & 6-ring & ARG & 403 & pi-cation & 4.09 \\
\hline 24 & $\mathrm{~N}$ & TYR & 449 & H-donor & 3.11 \\
\hline & & & & & \\
\hline
\end{tabular}


Table S7. Interaction report of each conformer of compound R6. Number of conformer, Atom of compound, Residue in RBD, Type of interaction and Distance in angstroms.

\begin{tabular}{|c|c|c|c|c|c|}
\hline \multirow{2}{*}{$\begin{array}{c}\text { Conformer } \\
1\end{array}$} & \multirow{2}{*}{\begin{tabular}{|l|} 
Ligand \\
5-ring
\end{tabular}} & \multicolumn{2}{|c|}{ Residues in RBD } & \multirow{2}{*}{$\begin{array}{c}\text { Interaction } \\
\text { pi-H }\end{array}$} & \multirow{2}{*}{$\begin{array}{r}\text { Distance } \\
4.61\end{array}$} \\
\hline & & LYS & 417 & & \\
\hline 2 & $\mathrm{C}$ & TYR & 505 & H-pi & 4.13 \\
\hline 3 & 5-ring & TYR & 505 & pi-H & 4.45 \\
\hline \multirow[t]{2}{*}{4} & 6-ring & GLY & 416 & pi-H & 4.01 \\
\hline & 6-ring & TYR & 505 & pi-H & 3.81 \\
\hline \multirow[t]{2}{*}{5} & 5-ring & LYS & 417 & pi-H & 4.22 \\
\hline & 6-ring & TYR & 505 & pi-H & 4.22 \\
\hline 6 & 6-ring & GLY & 416 & pi-H & 3.96 \\
\hline \multirow[t]{2}{*}{7} & 6-ring & ASN & 460 & pi-H & 3.61 \\
\hline & 6-ring & TYR & 505 & pi-H & 4.35 \\
\hline \multirow[t]{2}{*}{8} & 5-ring & LYS & 417 & pi-H & 4.19 \\
\hline & 6-ring & TYR & 505 & pi-H & 4.19 \\
\hline \multirow[t]{2}{*}{9} & $\mathrm{O}$ & ARG & 408 & H-acceptor & 2.96 \\
\hline & 5-ring & ARG & 403 & pi-cation & 3.57 \\
\hline 10 & 5-ring & LYS & 417 & pi-H & 4.64 \\
\hline \multirow[t]{2}{*}{11} & $\mathrm{~S}$ & GLN & 493 & H-donor & 3.66 \\
\hline & 5-ring & TYR & 505 & pi-H & 4.2 \\
\hline 12 & 5-ring & ARG & 403 & pi-cation & 3.45 \\
\hline 13 & 6-ring & TYR & 453 & pi-H & 3.58 \\
\hline 14 & 5-ring & ARG & 403 & pi-cation & 4.04 \\
\hline 15 & $\mathrm{O}$ & ARG & 403 & H-acceptor & 2.94 \\
\hline 16 & $\mathrm{~N}$ & ARG & 403 & H-acceptor & 3.04 \\
\hline \multirow[t]{3}{*}{17} & $\mathrm{~N}$ & GLN & 493 & H-acceptor & 3.24 \\
\hline & $\mathrm{N}$ & GLN & 493 & H-acceptor & 3.21 \\
\hline & 6-ring & TYR & 505 & pi-H & 3.88 \\
\hline \multirow[t]{3}{*}{18} & $\mathrm{~S}$ & SER & 494 & H-donor & 3.6 \\
\hline & $\mathrm{O}$ & TYR & 449 & H-acceptor & 3 \\
\hline & 5-ring & TYR & 453 & pi-H & 4.28 \\
\hline
\end{tabular}

Table S8. Interaction report of each conformer of compound R7. Number of conformer, Atom of compound, Residue in RBD, Type of interaction and Distance in angstroms.

\begin{tabular}{|c|c|c|c|c|c|}
\hline \multirow{2}{*}{$\begin{array}{c}\text { Conformer } \\
1\end{array}$} & \multirow{2}{*}{$\begin{array}{l}\text { Ligand } \\
S\end{array}$} & \multicolumn{2}{|c|}{ Residues in RBD } & \multirow{2}{*}{$\begin{array}{r}\text { Interaction } \\
\mathrm{H} \text {-acceptor }\end{array}$} & \multirow{2}{*}{$\begin{array}{c}\text { Distance } \\
3.6\end{array}$} \\
\hline & & ARG & 408 & & \\
\hline & $\mathrm{O}$ & ARG & 403 & H-acceptor & 2.87 \\
\hline & 6-ring & GLY & 496 & pi-H & 4.07 \\
\hline \multirow[t]{3}{*}{2} & $\mathrm{~S}$ & ARG & 408 & H-acceptor & 3.68 \\
\hline & $\mathrm{O}$ & ARG & 403 & H-acceptor & 2.88 \\
\hline & 6-ring & GLY & 496 & pi-H & 4.16 \\
\hline \multirow[t]{3}{*}{3} & $S$ & ARG & 408 & H-acceptor & 3.65 \\
\hline & $\mathrm{O}$ & ARG & 403 & $\mathrm{H}$-acceptor & 2.83 \\
\hline & 6-ring & GLY & 496 & pi-H & 4.16 \\
\hline \multirow[t]{3}{*}{4} & $\mathrm{~S}$ & ARG & 408 & $\mathrm{H}$-acceptor & 3.71 \\
\hline & $\mathrm{O}$ & ARG & 403 & $\mathrm{H}$-acceptor & 2.81 \\
\hline & 6-ring & GLY & 496 & pi-H & 4.13 \\
\hline 5 & $\mathrm{O}$ & ARG & 408 & H-acceptor & 3.03 \\
\hline \multirow[t]{2}{*}{6} & $\mathrm{O}$ & ARG & 408 & H-acceptor & 3.01 \\
\hline & $\mathrm{C}$ & TYR & 505 & pi-H & 4.57 \\
\hline 7 & 5-ring & GLY & 416 & pi-H & 3.78 \\
\hline \multirow[t]{2}{*}{8} & $\mathrm{O}$ & ARG & 408 & H-acceptor & 3.17 \\
\hline & 5-ring & GLN & 498 & pi-H & 3.88 \\
\hline 9 & 6-ring & GLY & 496 & pi-H & 4.13 \\
\hline 10 & 6-ring & GLY & 496 & pi-H & 3.95 \\
\hline \multirow[t]{2}{*}{11} & $\mathrm{O}$ & GLN & 498 & H-acceptor & 3.24 \\
\hline & 5-ring & GLY & 416 & pi-H & 3.98 \\
\hline 12 & 6-ring & GLY & 496 & pi-H & 3.92 \\
\hline
\end{tabular}




\begin{tabular}{|c|l|l|l|c|c|}
\hline Conformer & Ligand & \multicolumn{2}{|c|}{ Residues in RBD } & Interaction & Distance \\
\hline 13 & O & LYS & 417 & H-acceptor & 3.19 \\
\hline 14 & O & ARG & 408 & H-acceptor & 3.04 \\
\hline 15 & 5-ring & GLY & 446 & pi-H & 4.45 \\
\hline & 6-ring & GLY & 496 & pi-H & 4.29 \\
\hline 16 & 6-ring & TYR & 505 & pi-H & 4.17 \\
\hline & 6-ring & TYR & 505 & pi-H & 4.04 \\
\hline 17 & S & THR & 500 & H-acceptor & 4.32 \\
\hline & 5-ring & GLN & 498 & pi-H & 3.9 \\
\hline 18 & 5-ring & GLN & 498 & pi-H & 3.95 \\
\hline 19 & S & THR & 500 & H-acceptor & 3.82 \\
\hline & O & LYS & 417 & H-acceptor & 3.02 \\
\hline & 5-ring & GLN & 498 & pi-H & 3.78 \\
\hline & 6-ring & TYR & 505 & pi-H & 3.52 \\
\hline & S & LYS & 417 & H-acceptor & 3.79 \\
\hline & O & ARG & 403 & H-acceptor & 3 \\
\hline 21 & 6-ring & GLY & 496 & pi-H & 4.11 \\
\hline & S & TYR & 449 & H-acceptor & 4.28 \\
\hline & S & GLN & 498 & H-acceptor & 4.39 \\
\hline & S & LYS & 417 & H-acceptor & 4.2 \\
\hline
\end{tabular}

Table S9. Interaction report of each conformer of compound R8. Number of conformer, Atom of compound, Residue in RBD, Type of interaction and Distance in angstroms.

\begin{tabular}{|c|c|c|c|c|c|}
\hline \multirow{2}{*}{$\begin{array}{c}\text { Conformer } \\
1\end{array}$} & \multirow{2}{*}{$\begin{array}{l}\text { Ligand } \\
\text { 6-ring }\end{array}$} & \multicolumn{2}{|c|}{ Residues in RBD } & \multirow{2}{*}{$\begin{array}{c}\text { Interaction } \\
\text { pi-H }\end{array}$} & \multirow{2}{*}{$\begin{array}{r}\text { Distance } \\
3.65\end{array}$} \\
\hline & & GLY & 496 & & \\
\hline \multirow[t]{2}{*}{2} & $\mathrm{~S}$ & GLU & 406 & H-donor & 3.71 \\
\hline & 6-ring & TYR & 449 & pi-H & 4.57 \\
\hline \multirow[t]{2}{*}{3} & $\mathrm{~N}$ & GLU & 406 & H-donor & 3.33 \\
\hline & 6-ring & TYR & 449 & pi-H & 4.54 \\
\hline \multirow[t]{3}{*}{4} & $\mathrm{~S}$ & GLU & 406 & H-donor & 3.98 \\
\hline & $\mathrm{N}$ & GLU & 406 & H-donor & 3.32 \\
\hline & 6-ring & TYR & 449 & pi-H & 4.63 \\
\hline \multirow[t]{2}{*}{5} & $\mathrm{~N}$ & ARG & 403 & H-acceptor & 3.2 \\
\hline & $\mathrm{O}$ & LYS & 417 & H-acceptor & 3.26 \\
\hline \multirow[t]{2}{*}{6} & 6-ring & GLN & 498 & pi-H & 4.09 \\
\hline & 5-ring & GLY & 504 & pi-H & 4.1 \\
\hline 7 & 6-ring & GLY & 496 & pi-H & 3.53 \\
\hline 8 & $\mathrm{~N}$ & GLU & 406 & H-donor & 3.19 \\
\hline \multirow[t]{2}{*}{9} & $\mathrm{O}$ & TYR & 453 & H-acceptor & 3.09 \\
\hline & 6-ring & GLY & 496 & pi-H & 3.86 \\
\hline \multirow[t]{3}{*}{10} & $\mathrm{~S}$ & GLN & 409 & H-donor & 3.94 \\
\hline & S & GLY & 502 & H-donor & 3.55 \\
\hline & $\mathrm{O}$ & ARG & 403 & H-acceptor & 3.43 \\
\hline \multirow[t]{2}{*}{11} & $S$ & GLU & 406 & H-donor & 4.07 \\
\hline & $\mathrm{N}$ & GLU & 406 & H-donor & 3.23 \\
\hline 12 & $S$ & GLU & 406 & H-donor & 3.96 \\
\hline 13 & 6-ring & THR & 500 & pi-H & 3.88 \\
\hline 14 & 6-ring & LYS & 417 & pi-cation & 4.58 \\
\hline \multirow[t]{2}{*}{15} & 6-ring & GLN & 498 & pi-H & 4.49 \\
\hline & 5-ring & GLY & 504 & pi-H & 4.2 \\
\hline 16 & $\mathrm{O}$ & ARG & 403 & H-acceptor & 2.9 \\
\hline \multirow[t]{2}{*}{17} & $\mathrm{O}$ & GLY & 496 & H-acceptor & 3.37 \\
\hline & 6-ring & GLN & 498 & pi-H & 3.7 \\
\hline \multirow[t]{2}{*}{18} & $S$ & ASP & 420 & H-donor & 3.7 \\
\hline & 5-ring & THR & 415 & pi-H & 4.44 \\
\hline \multirow[t]{2}{*}{19} & $\mathrm{O}$ & TYR & 449 & H-acceptor & 3.05 \\
\hline & 6-ring & GLY & 502 & pi-H & 3.93 \\
\hline 20 & 6-ring & TYR & 505 & pi-H & 4.17 \\
\hline
\end{tabular}


Table S10. Interaction report of each conformer of compound R9. Number of conformer, Atom of compound,

Residue in RBD, Type of interaction and Distance in angstroms.

\begin{tabular}{|c|c|c|c|c|c|}
\hline \multirow{2}{*}{$\begin{array}{c}\text { Conformer } \\
1\end{array}$} & \multirow{2}{*}{$\begin{array}{l}\text { Ligand } \\
\mathrm{O}\end{array}$} & \multicolumn{2}{|c|}{ Residues in RBD } & \multirow{2}{*}{$\begin{array}{r}\text { Interaction } \\
\text { H-donor }\end{array}$} & \multirow{2}{*}{$\begin{array}{c}\text { Distance } \\
3.04\end{array}$} \\
\hline & & GLY & 496 & & \\
\hline 2 & 6-ring & ALA & 475 & pi-H & 4.3 \\
\hline \multirow[t]{3}{*}{3} & $\mathrm{O}$ & SER & 494 & H-donor & 2.97 \\
\hline & $\mathrm{O}$ & ARG & 403 & H-acceptor & 3.17 \\
\hline & 6-ring & TYR & 505 & pi-H & 3.88 \\
\hline 4 & 6-ring & LYS & 417 & pi-H & 4.33 \\
\hline 5 & 6-ring & TYR & 495 & pi-H & 4.4 \\
\hline 6 & 6-ring & TYR & 505 & pi-H & 4.13 \\
\hline 7 & 6-ring & ARG & 403 & pi-cation & 3.47 \\
\hline \multirow[t]{2}{*}{8} & $\mathrm{O}$ & GLY & 496 & H-donor & 3.12 \\
\hline & 6-ring & GLY & 502 & pi-H & 3.96 \\
\hline \multirow[t]{3}{*}{9} & $\mathrm{O}$ & SER & 494 & H-donor & 2.9 \\
\hline & $\mathrm{O}$ & GLY & 496 & H-donor & 3.01 \\
\hline & 6-ring & THR & 500 & pi-H & 3.61 \\
\hline \multirow[t]{2}{*}{10} & $\mathrm{O}$ & GLY & 502 & H-acceptor & 3.44 \\
\hline & 6-ring & TYR & 505 & pi-H & 4 \\
\hline 11 & $\mathrm{O}$ & GLY & 496 & H-acceptor & 3.16 \\
\hline 12 & 6-ring & LYS & 417 & pi-H & 4.13 \\
\hline \multirow[t]{2}{*}{13} & $\mathrm{O}$ & ARG & 403 & H-acceptor & 2.95 \\
\hline & 6-ring & TYR & 453 & pi-H & 3.38 \\
\hline 14 & $\mathrm{O}$ & GLY & 496 & H-acceptor & 3.15 \\
\hline \multirow[t]{4}{*}{15} & $\mathrm{O}$ & SER & 494 & H-donor & 3.06 \\
\hline & $\mathrm{O}$ & GLY & 496 & H-donor & 3 \\
\hline & $\mathrm{O}$ & TYR & 505 & H-acceptor & 3.06 \\
\hline & 6-ring & THR & 500 & pi-H & 3.54 \\
\hline \multirow[t]{2}{*}{16} & $\mathrm{O}$ & GLY & 496 & H-acceptor & 3.19 \\
\hline & 6-ring & GLY & 502 & pi-H & 4.02 \\
\hline 17 & $\mathrm{O}$ & GLY & 496 & H-acceptor & 3.12 \\
\hline \multirow[t]{2}{*}{18} & 6-ring & ARG & 403 & pi-cation & 3.87 \\
\hline & 6-ring & THR & 500 & pi-H & 3.73 \\
\hline \multirow[t]{3}{*}{19} & $\mathrm{O}$ & GLY & 496 & H-donor & 3.18 \\
\hline & 6-ring & ARG & 403 & pi-cation & 3.86 \\
\hline & 6-ring & THR & 500 & pi-H & 3.67 \\
\hline \multirow[t]{2}{*}{20} & 6-ring & ARG & 403 & pi-cation & 3.71 \\
\hline & 6-ring & LYS & 417 & pi-H & 4.22 \\
\hline \multirow[t]{2}{*}{21} & 6-ring & ARG & 403 & pi-cation & 3.59 \\
\hline & 6-ring & TYR & 449 & pi-H & 3.61 \\
\hline \multirow[t]{2}{*}{22} & $\mathrm{O}$ & ARG & 403 & H-acceptor & 3.05 \\
\hline & 6-ring & GLY & 502 & pi-H & 3.74 \\
\hline 23 & $\mathrm{O}$ & GLY & 496 & H-acceptor & 3.22 \\
\hline 24 & 6-ring & ARG & 403 & pi-cation & 3.56 \\
\hline
\end{tabular}

Table S11. Interaction report of each conformer of compound R10. Number of conformer, Atom of compound, Residue in RBD, Type of interaction and Distance in angstroms.

\begin{tabular}{|c|l|c|c|c|c|}
\hline Conformer & Ligand & \multicolumn{2}{|c|}{ Residues in RBD } & Interaction & Distance \\
\hline 1 & 6-ring & ARG & 408 & pi-cation & 3.97 \\
\hline & 6-ring & ARG & 408 & pi-cation & 4.48 \\
\hline & 6-ring & GLY & 496 & pi-H & 3.9 \\
\hline 2 & O & TYR & 449 & H-acceptor & 2.82 \\
\hline 3 & O & ASN & 460 & H-acceptor & 3.11 \\
\hline & 6-ring & GLY & 416 & pi-H & 3.99 \\
\hline & 6-ring & TYR & 453 & pi-H & 3.7 \\
\hline 4 & O & LYS & 417 & H-acceptor & 3.37 \\
\hline & 5-ring & LYS & 417 & pi-H & 4.23 \\
\hline & 6-ring & LYS & 417 & pi-cation & 3.68 \\
\hline
\end{tabular}




\begin{tabular}{|c|c|c|c|c|c|}
\hline \multirow{2}{*}{$\begin{array}{c}\text { Conformer } \\
5\end{array}$} & \multirow{2}{*}{$\begin{array}{l}\text { Ligand } \\
\mathrm{O}\end{array}$} & \multicolumn{2}{|c|}{ Residues in RBD } & \multirow{2}{*}{$\begin{array}{c}\text { Interaction } \\
\text { H-acceptor }\end{array}$} & \multirow{2}{*}{$\begin{array}{c}\text { Distance } \\
3.16\end{array}$} \\
\hline & & ARG & 403 & & \\
\hline \multirow[t]{3}{*}{6} & $\mathrm{O}$ & GLY & 496 & H-acceptor & 3.48 \\
\hline & 5-ring & LYS & 417 & pi-H & 4.32 \\
\hline & 6-ring & LYS & 417 & pi-cation & 4.68 \\
\hline \multirow[t]{3}{*}{7} & $\mathrm{O}$ & GLY & 496 & H-acceptor & 3.15 \\
\hline & 5-ring & LYS & 417 & pi-H & 4.12 \\
\hline & 6-ring & LYS & 417 & pi-cation & 4.11 \\
\hline 8 & $\mathrm{O}$ & TYR & 449 & H-acceptor & 3.02 \\
\hline \multirow[t]{3}{*}{9} & $\mathrm{O}$ & GLN & 409 & H-acceptor & 3.18 \\
\hline & $\mathrm{O}$ & LYS & 417 & H-acceptor & 3.31 \\
\hline & 6-ring & TYR & 505 & pi-H & 3.94 \\
\hline \multirow[t]{3}{*}{10} & 5-ring & LYS & 417 & pi-H & 4.39 \\
\hline & 6-ring & LYS & 417 & pi-cation & 4.71 \\
\hline & 6-ring & TYR & 505 & pi-H & 4.18 \\
\hline 11 & $\mathrm{O}$ & GLY & 496 & H-acceptor & 3.25 \\
\hline \multirow[t]{3}{*}{12} & $\mathrm{O}$ & GLY & 496 & H-acceptor & 3.14 \\
\hline & 5-ring & LYS & 417 & pi-H & 4.32 \\
\hline & 6-ring & LYS & 417 & pi-cation & 3.96 \\
\hline 13 & 6-ring & GLY & 502 & pi-H & 4.7 \\
\hline 14 & $\mathrm{O}$ & TYR & 449 & H-acceptor & 2.87 \\
\hline 15 & $\mathrm{O}$ & ARG & 403 & H-acceptor & 3.43 \\
\hline \multirow[t]{3}{*}{16} & $\mathrm{C}$ & TYR & 505 & H-acceptor & 4.51 \\
\hline & 6-ring & GLY & 502 & pi-H & 4.24 \\
\hline & 6-ring & TYR & 505 & pi-H & 4.59 \\
\hline \multirow[t]{2}{*}{17} & 6-ring & GLY & 416 & pi-H & 3.86 \\
\hline & 5-ring & LYS & 417 & pi-H & 4.19 \\
\hline 18 & 6-ring & ARG & 403 & pi-cation & 3.69 \\
\hline 19 & 6-ring & ARG & 403 & pi-cation & 3.67 \\
\hline \multirow[t]{2}{*}{20} & 6-ring & ARG & 403 & pi-cation & 4.51 \\
\hline & 6-ring & TYR & 505 & pi-H & 3.69 \\
\hline 21 & 6-ring & TYR & 505 & pi-H & 4.13 \\
\hline \multirow[t]{2}{*}{22} & $\mathrm{O}$ & ARG & 408 & H-acceptor & 2.96 \\
\hline & 6-ring & $\mathrm{ARG}$ & 403 & pi-cation & 3.86 \\
\hline
\end{tabular}

Table S12. Toxicity - PreADMET | Prediction of ADME/Tox of compounds R1-R10.

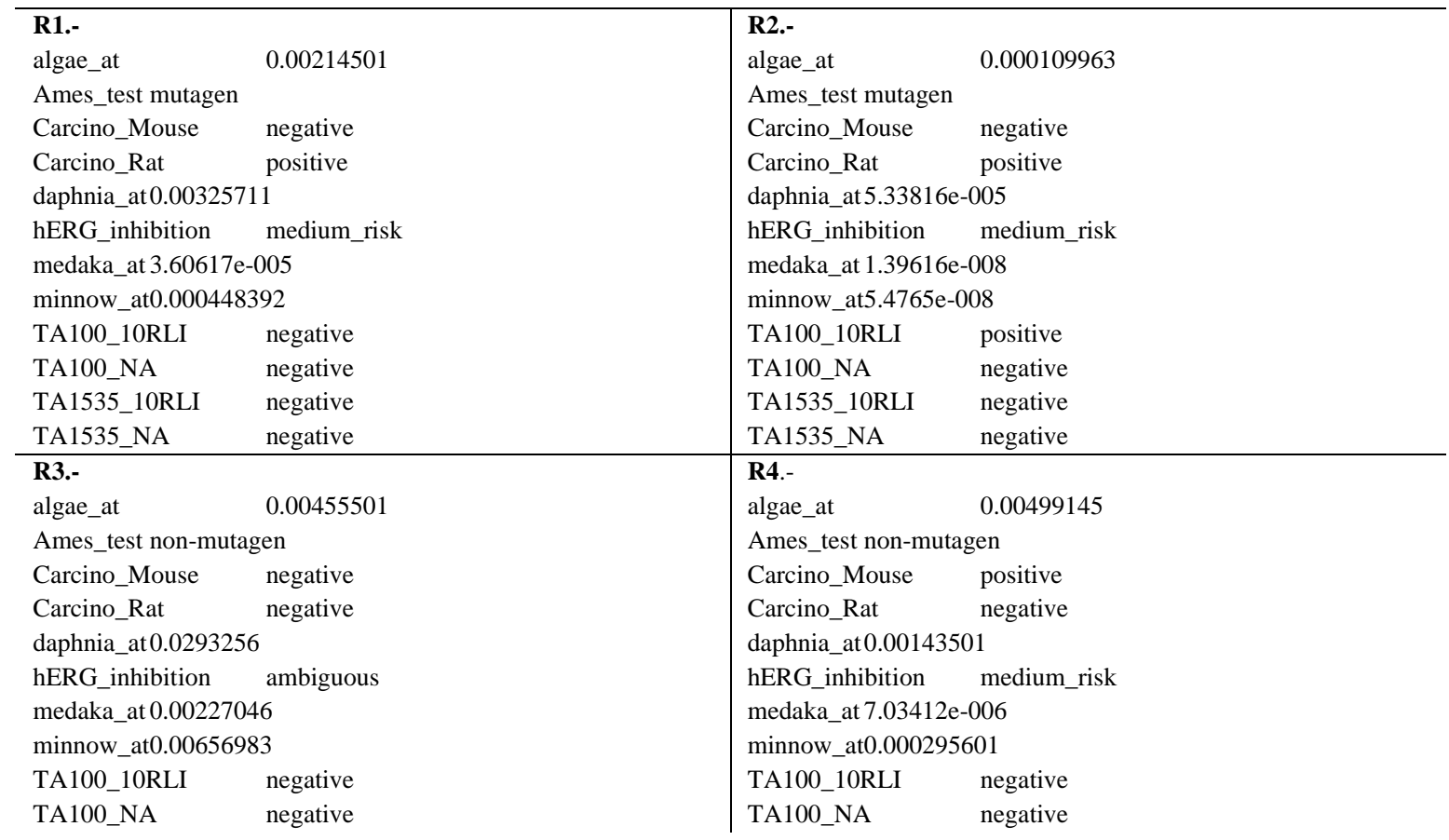




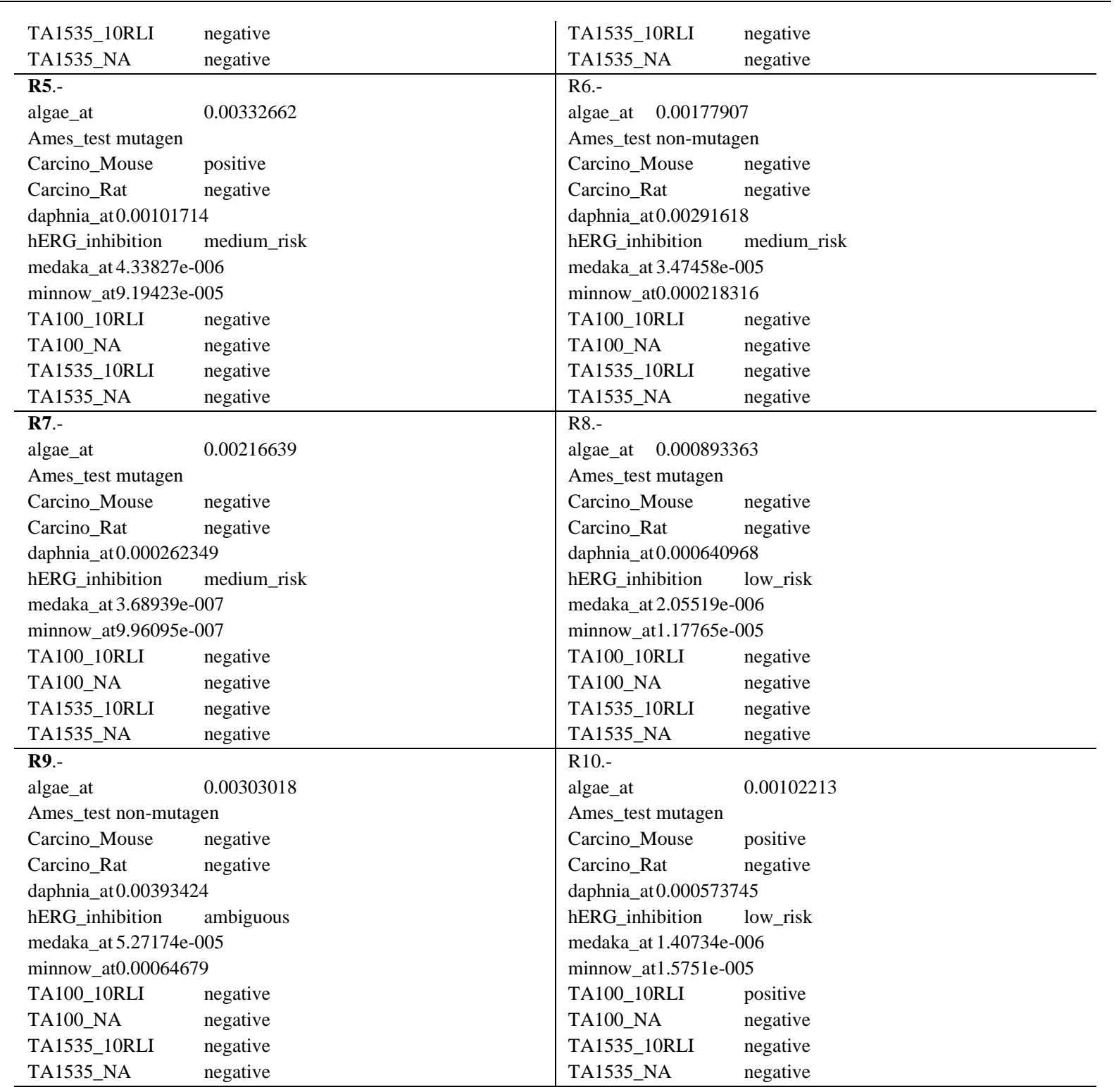

Table S13. ADME - PreADMET | Prediction of ADME/Tox of compounds R1-R10.

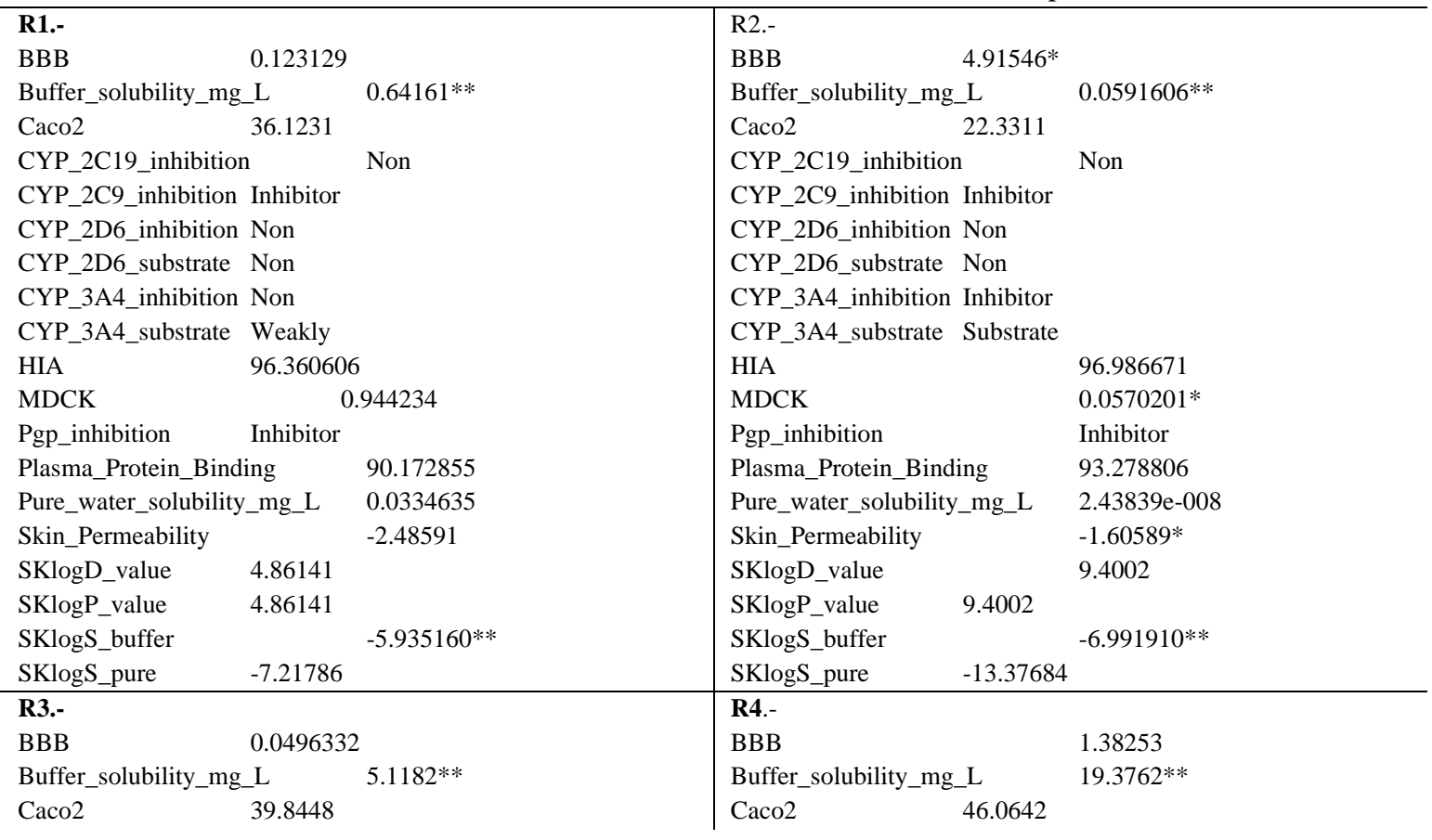




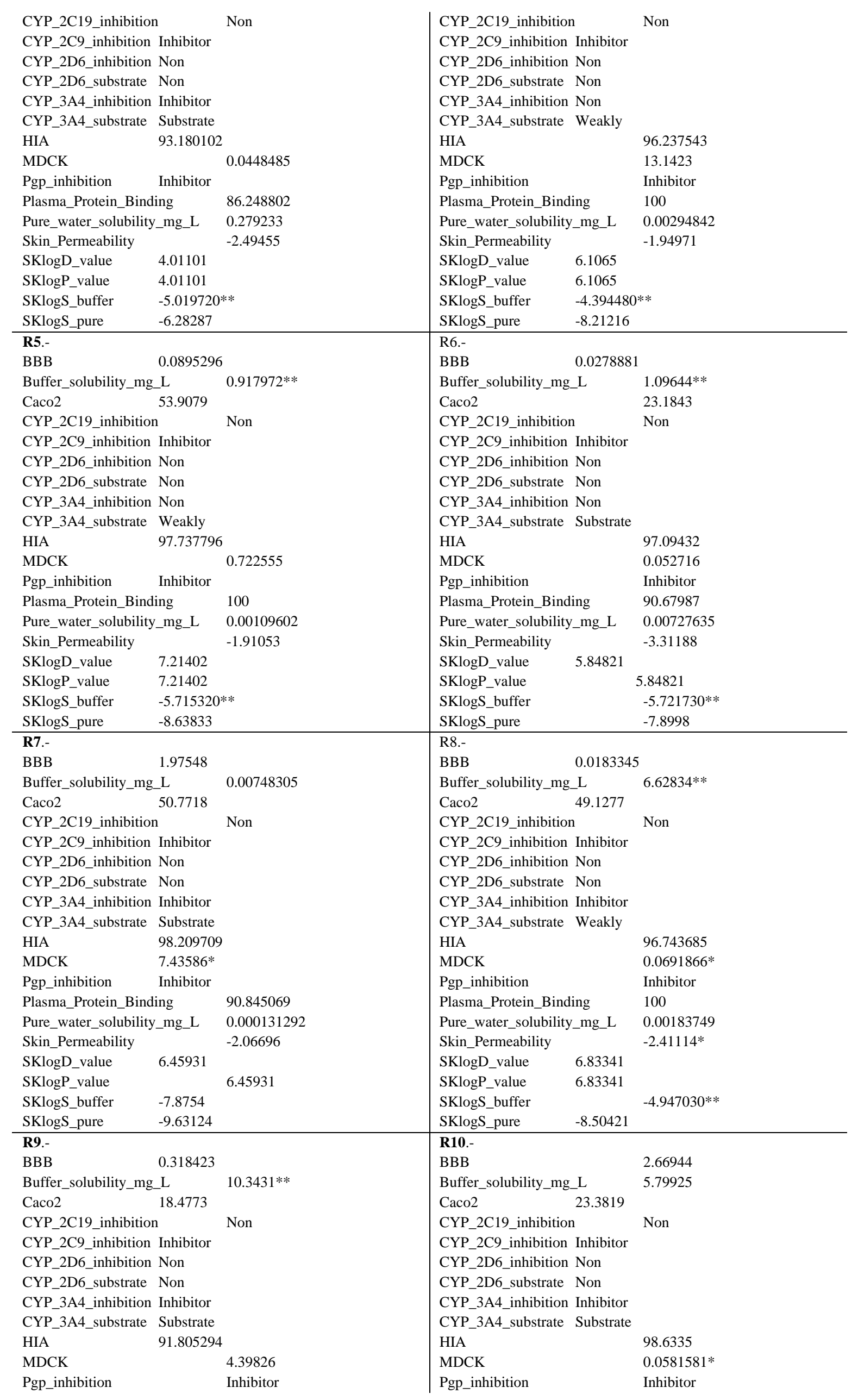

https://biointerfaceresearch.com/ 


\begin{tabular}{|c|c|c|c|c|c|}
\hline \multirow{3}{*}{\multicolumn{2}{|c|}{$\begin{array}{l}\text { Plasma_Protein_Binding } \\
\text { Pure_water_solubility_mg_L } \\
\text { Skin_Permeability }\end{array}$}} & 91.723294 & \multicolumn{2}{|c|}{ Plasma_Protein_Binding } & 96.977388 \\
\hline & & 0.0309251 & Pure_water_sol & y_mg_L & 0.00016586 \\
\hline & & $-2.80001^{*}$ & Skin_Permeabil & & $-1.75733^{*}$ \\
\hline SKlogD_value & 4.76377 & & SKlogD_value & & 6.83969 \\
\hline SKlogP_value & & 4.76377 & SKlogP_value & 6.83969 & \\
\hline SKlogS_buffer & -4.7324 & & SKlogS_buffer & & -4.98917 \\
\hline SKlogS_pure & $-7.2567\}$ & & SKlogS_pure & -9.5328 & \\
\hline
\end{tabular}

Table S14. Properties predicted by PhysChem - ACD/Labs of compounds R1-R10.

\begin{tabular}{|c|c|c|c|}
\hline \multicolumn{2}{|l|}{ R1.- } & \multicolumn{2}{|l|}{ R2.- } \\
\hline & $1.3 \pm 0.1 \mathrm{~g} / \mathrm{cm} 3$ & Density & $1.2 \pm 0.1 \mathrm{~g} / \mathrm{cm} 3$ \\
\hline Boiling Point: & $823.7 \pm 65.0^{\circ} \mathrm{C}$ at $760 \mathrm{mmHg}$ & Boiling Point: & $675.2 \pm 55.0^{\circ} \mathrm{C}$ at $760 \mathrm{mmHg}$ \\
\hline Vapour Pressure: & $0.0 \pm 3.0 \mathrm{mmHg}$ at $25^{\circ} \mathrm{C}$ & Vapour Pressure & $0.0 \pm 2.1 \mathrm{mmHg}$ at $25^{\circ} \mathrm{C}$ \\
\hline \multicolumn{2}{|c|}{ Enthalpy of Vaporization: $\quad 119.7 \pm 3.0 \mathrm{~kJ} / \mathrm{mol}$} & Enthalpy of Vaporization: & $99.1 \pm 3.0 \mathrm{~kJ} / \mathrm{mol}$ \\
\hline Flash Point: & $451.9 \pm 34.3^{\circ} \mathrm{C}$ & \multicolumn{2}{|c|}{ Flash Point: } \\
\hline Index of Refraction: & 1.653 & \multicolumn{2}{|c|}{ Index of Refraction: 1.637} \\
\hline Molar Refractivity: & $158.0 \pm 0.3 \mathrm{~cm} 3$ & Molar Refractivity: & $175.0 \pm 0.5 \mathrm{~cm} 3$ \\
\hline \#H bond acceptors: & 8 & \multicolumn{2}{|l|}{ \#H bond acceptors: 8} \\
\hline \#H bond donors: & 2 & \#H bond donors: & 2 \\
\hline \multicolumn{2}{|l|}{$\begin{array}{l}\text { \#Freely Rotating Bonds: } \\
\text { \#Rule of } 5 \text { Violations: } 1\end{array}$} & $\begin{array}{l}\text { \#Freely Rotating Bonds: } \\
\text { \#Rule of } 5 \text { Violations: } 2\end{array}$ & $\begin{array}{l}\text { ds: } \\
2\end{array}$ \\
\hline $\mathrm{ACD} / \log \mathrm{P}:$ & 4.43 & $\mathrm{ACD} / \log \mathrm{P}:$ & 8.18 \\
\hline $\mathrm{ACD} / \log \mathrm{D}(\mathrm{pH} 5.5):$ & 4.49 & $\mathrm{ACD} / \operatorname{LogD}(\mathrm{pH} 5.5)$ : & 7.78 \\
\hline $\mathrm{ACD} / \mathrm{BCF}(\mathrm{pH} 5.5):$ & 1512.25 & $\mathrm{ACD} / \mathrm{BCF}$ (pH 5.5): & 479472.53 \\
\hline $\mathrm{ACD} / \mathrm{KOC}(\mathrm{pH} 5.5):$ & 6570.06 & $\mathrm{ACD} / \mathrm{KOC}(\mathrm{pH} 5.5)$ : & 405380.16 \\
\hline $\mathrm{ACD} / \log \mathrm{D}(\mathrm{pH} 7.4):$ & 4.49 & $\mathrm{ACD} / \operatorname{LogD}(\mathrm{pH} 7.4)$ : & 7.78 \\
\hline $\mathrm{ACD} / \mathrm{BCF}(\mathrm{pH} 7.4):$ & 1512.3 & $\mathrm{ACD} / \mathrm{BCF}(\mathrm{pH} 7.4)$ : & 479464.09 \\
\hline $\mathrm{ACD} / \mathrm{KOC}(\mathrm{pH} 7.4):$ & 6570.27 & $\mathrm{ACD} / \mathrm{KOC}(\mathrm{pH} 7.4)$ : & 405373.03 \\
\hline Polar Surface Area: & $95 \AA ̊ 2$ & Polar Surface Area: & $108 \AA 2$ \\
\hline Polarizability: & $62.6 \pm 0.5 \quad 10-24 \mathrm{~cm} 3$ & Polarizability: & $69.4 \pm 0.5 \quad 10-24 \mathrm{~cm} 3$ \\
\hline Surface Tension: & $53.0 \pm 3.0 \mathrm{dyne} / \mathrm{cm}$ & Surface Tension: & $46.0 \pm 7.0 \mathrm{dyne} / \mathrm{cm}$ \\
\hline Molar Volume: & $431.9 \pm 3.0 \mathrm{~cm} 3$ & Molar Volume: & $487.8 \pm 7.0 \mathrm{~cm} 3$ \\
\hline R3.- & & R4.- & \\
\hline Density: & $1.2 \pm 0.1 \mathrm{~g} / \mathrm{cm} 3$ & Density: & $1.2 \pm 0.1 \mathrm{~g} / \mathrm{cm} 3$ \\
\hline Boiling Point: & $762.4 \pm 60.0^{\circ} \mathrm{C}$ at $760 \mathrm{mmHg}$ & Boiling Point: & $765.6 \pm 60.0^{\circ} \mathrm{C}$ at $760 \mathrm{mmHg}$ \\
\hline Vapour Pressure: & $0.0 \pm 2.6 \mathrm{mmHg}$ at $25^{\circ} \mathrm{C}$ & Vapour Pressure: & $0.0 \pm 2.6 \mathrm{mmHg}$ at $25^{\circ} \mathrm{C}$ \\
\hline Enthalpy of Vaporizati & tion: $\quad 111.0 \pm 3.0 \mathrm{~kJ} / \mathrm{mol}$ & Enthalpy of Vaporiza & $111.5 \pm 3.0 \mathrm{~kJ} / \mathrm{mol}$ \\
\hline Flash Point: & $414.9 \pm 32.9^{\circ} \mathrm{C}$ & Flash Point: & $416.8 \pm 32.9^{\circ} \mathrm{C}$ \\
\hline Index of Refraction: & 1.605 & Index of Refraction: & 1.645 \\
\hline Molar Refractivity: & $148.1 \pm 0.3 \mathrm{~cm} 3$ & Molar Refractivity: & $141.5 \pm 0.3 \mathrm{~cm} 3$ \\
\hline \#H bond acceptors: & 10 & \#H bond acceptors: & 6 \\
\hline \#H bond donors: & 3 & \#H bond donors: & 2 \\
\hline \#Freely Rotating Bond & 12 & \#Freely Rotating Bon & ds: \\
\hline \#Rule of 5 Violations: & & \#Rule of 5 Violations & \\
\hline $\mathrm{ACD} / \log \mathrm{P}:$ & 4.01 & $\mathrm{ACD} / \log \mathrm{P}:$ & 6.53 \\
\hline $\mathrm{ACD} / \operatorname{LogD}(\mathrm{pH} 5.5): 3$ & 3.27 & $\mathrm{ACD} / \operatorname{LogD}(\mathrm{pH} 5.5)$ : & 5.89 \\
\hline $\mathrm{ACD} / \mathrm{BCF}(\mathrm{pH} 5.5):$ & 180.94 & $\mathrm{ACD} / \mathrm{BCF}(\mathrm{pH} 5.5)$ : & 17581.53 \\
\hline $\mathrm{ACD} / \mathrm{KOC}(\mathrm{pH} 5.5):$ & 1437.3 & $\mathrm{ACD} / \mathrm{KOC}(\mathrm{pH} 5.5)$ : & 38036.09 \\
\hline $\mathrm{ACD} / \log \mathrm{D}(\mathrm{pH} 7.4): 3$ & 3.27 & $\mathrm{ACD} / \operatorname{LogD}(\mathrm{pH} 7.4)$ : & 5.89 \\
\hline $\mathrm{ACD} / \mathrm{BCF}(\mathrm{pH} 7.4):$ & 180.94 & $\mathrm{ACD} / \mathrm{BCF}(\mathrm{pH} 7.4)$ : & 17581.88 \\
\hline $\mathrm{ACD} / \mathrm{KOC}(\mathrm{pH} 7.4):$ & 1437.29 & $\mathrm{ACD} / \mathrm{KOC}(\mathrm{pH} 7.4)$ : & 38036.84 \\
\hline Polar Surface Area: & $124 \AA 2$ & Polar Surface Area: & $77 \AA 2$ \\
\hline Polarizability: & $58.7 \pm 0.510-24 \mathrm{~cm} 3$ & Polarizability: & $56.1 \pm 0.510-24 \mathrm{~cm} 3$ \\
\hline Surface Tension: & $49.2 \pm 3.0 \mathrm{dyne} / \mathrm{cm}$ & Surface Tension: & $51.9 \pm 3.0$ dyne $/ \mathrm{cm}$ \\
\hline Molar Volume: & $430.3 \pm 3.0 \mathrm{~cm} 3$ & Molar Volume: & $390.2 \pm 3.0 \mathrm{~cm} 3$ \\
\hline R5.- & & R6.- & \\
\hline Density: & $1.2 \pm 0.1 \mathrm{~g} / \mathrm{cm} 3$ & Density: & $1.4 \pm 0.1 \mathrm{~g} / \mathrm{cm} 3$ \\
\hline Boiling Point: & & Boiling Point: & \\
\hline Vapour Pressure: & & Vapour Pressure: & \\
\hline Enthalpy of Vaporizati & tion: & Enthalpy of Vaporiza & tion: \\
\hline Flash Point: & & Flash Point: & \\
\hline Index of Refraction: & 1.662 & Index of Refraction: & 1.682 \\
\hline Molar Refractivity: & $145.1 \pm 0.5 \mathrm{~cm} 3$ & Molar Refractivity: & $159.4 \pm 0.5 \mathrm{~cm} 3$ \\
\hline \#H bond acceptors: & 5 & \#H bond acceptors: & 9 \\
\hline \#H bond donors: & 1 & \#H bond donors: & 2 \\
\hline $\begin{array}{l}\text { \#Freely Rotating Bond } \\
\text { \#Rule of } 5 \text { Violations: }\end{array}$ & $\begin{array}{l}\text { ds: } \\
: 1\end{array}$ & $\begin{array}{l}\text { \#Freely Rotating Bon } \\
\text { \#Rule of } 5 \text { Violations }\end{array}$ & $\begin{array}{l}\text { ds: } \\
2\end{array}$ \\
\hline
\end{tabular}




\begin{tabular}{|c|c|c|c|}
\hline $\mathrm{ACD} / \log \mathrm{P}:$ & 7.82 & $\mathrm{ACD} / \log \mathrm{P}:$ & 6.91 \\
\hline $\mathrm{ACD} / \operatorname{LogD}(\mathrm{pH} 5.5):$ & 6.36 & \multicolumn{2}{|c|}{$\mathrm{ACD} / \log \mathrm{D}(\mathrm{pH} 5.5): 5.05$} \\
\hline $\mathrm{ACD} / \mathrm{BCF}(\mathrm{pH} 5.5):$ & 40195.15 & \multicolumn{2}{|c|}{ ACD/BCF (pH 5.5): $\quad 4037.03$} \\
\hline $\mathrm{ACD} / \mathrm{KOC}(\mathrm{pH} 5.5)$ : & 68744.55 & \multicolumn{2}{|c|}{$\mathrm{ACD} / \mathrm{KOC}(\mathrm{pH} 5.5): 13268.15$} \\
\hline $\mathrm{ACD} / \log \mathrm{D}(\mathrm{pH} 7.4)$ : & 6.36 & \multicolumn{2}{|c|}{$\mathrm{ACD} / \operatorname{LogD}(\mathrm{pH} 7.4): 5.05$} \\
\hline $\mathrm{ACD} / \mathrm{BCF}(\mathrm{pH} 7.4)$ & 40199.12 & \multicolumn{2}{|c|}{$\mathrm{ACD} / \mathrm{BCF}(\mathrm{pH} 7.4): 4037.06$} \\
\hline $\mathrm{ACD} / \mathrm{KOC}(\mathrm{pH} 7.4)$ & 68751.35 & \multicolumn{2}{|c|}{ ACD/KOC (pH 7.4): $\quad 13268.24$} \\
\hline Polar Surface Area: & $85 \AA 2$ & \multicolumn{2}{|c|}{ Polar Surface Area: $161 \AA 2$} \\
\hline Polarizability: & $57.5 \pm 0.510-24 \mathrm{~cm} 3$ & Polarizability: $\quad 63.2 \pm 0.510-24 \mathrm{~cm} 3$ & $63.2 \pm 0.510-24 \mathrm{~cm} 3$ \\
\hline Surface Tension: & $49.7 \pm 7.0$ dyne $/ \mathrm{cm}$ & Surface Tension: & $55.3 \pm 7.0 \mathrm{dyne} / \mathrm{cm}$ \\
\hline Molar Volume: & $392.2 \pm 7.0 \mathrm{~cm} 3$ & \multicolumn{2}{|l|}{ Molar Volume: } \\
\hline R7.- & & \multicolumn{2}{|l|}{ R8.- } \\
\hline Density: & $1.4 \pm 0.1 \mathrm{~g} / \mathrm{cm} 3$ & Density: & $1.3 \pm 0.1 \mathrm{~g} / \mathrm{cm} 3$ \\
\hline Boiling Point: & $722.2 \pm 70.0^{\circ} \mathrm{C}$ at $760 \mathrm{mmHg}$ & Boiling Point: & $804.8 \pm 65.0^{\circ} \mathrm{C}$ at $760 \mathrm{mmHg}$ \\
\hline Vapour Pressure: & $0.0 \pm 2.3 \mathrm{mmHg}$ at $25^{\circ} \mathrm{C}$ & Vapour Pressure: & $0.0 \pm 2.9 \mathrm{mmHg}$ at $25^{\circ} \mathrm{C}$ \\
\hline Enthalpy of Vaporizat & tion: $\quad 105.5 \pm 3.0 \mathrm{~kJ} / \mathrm{mol}$ & Enthalpy of Vaporizati & $117.0 \pm 3.0 \mathrm{~kJ} / \mathrm{mol}$ \\
\hline Flash Point: & $390.6 \pm 35.7^{\circ} \mathrm{C}$ & Flash Point: & $440.6 \pm 34.3^{\circ} \mathrm{C}$ \\
\hline Index of Refraction: & 1.673 & Index of Refraction: & 1.706 \\
\hline Molar Refractivity: & $155.6 \pm 0.4 \mathrm{~cm} 3$ & Molar Refractivity: & $170.5 \pm 0.3 \mathrm{~cm} 3$ \\
\hline \#H bond acceptors: & 7 & \#H bond acceptors: & 6 \\
\hline \#H bond donors: & 0 & \#H bond donors: 2 & 2 \\
\hline \#Freely Rotating Bond & 12 & \#Freely Rotating Bond & ds: \\
\hline \#Rule of 5 Violations: & & \#Rule of 5 Violations: & \\
\hline ACD/LogP: & 5.27 & $\mathrm{ACD} / \log \mathrm{P}:$ & 6.87 \\
\hline $\mathrm{ACD} / \operatorname{LogD}(\mathrm{pH} 5.5)$ & 4.64 & $\mathrm{ACD} / \operatorname{LogD}(\mathrm{pH} 5.5):$ & 6.29 \\
\hline $\mathrm{ACD} / \mathrm{BCF}(\mathrm{pH} 5.5):$ & 1997.15 & $\mathrm{ACD} / \mathrm{BCF}(\mathrm{pH} 5.5)$ : & 35293.42 \\
\hline $\mathrm{ACD} / \mathrm{KOC}(\mathrm{pH} 5.5)$ : & 8017.33 & $\mathrm{ACD} / \mathrm{KOC}(\mathrm{pH} 5.5):$ & 62634.34 \\
\hline $\mathrm{ACD} / \operatorname{LogD}(\mathrm{pH} 7.4)$ & 4.64 & $\mathrm{ACD} / \operatorname{LogD}(\mathrm{pH} 7.4):$ & 6.29 \\
\hline $\mathrm{ACD} / \mathrm{BCF}(\mathrm{pH} 7.4):$ & 1997.15 & $\mathrm{ACD} / \mathrm{BCF}(\mathrm{pH} 7.4)$ : & 35296.25 \\
\hline $\mathrm{ACD} / \mathrm{KOC}(\mathrm{pH} 7.4)$ : & 8017.33 & $\mathrm{ACD} / \mathrm{KOC}(\mathrm{pH} 7.4):$ & 62639.36 \\
\hline Polar Surface Area: & $132 \AA 2$ & Polar Surface Area: & $140 \AA 2$ \\
\hline Polarizability: & $61.7 \pm 0.5 \quad 10-24 \mathrm{~cm} 3$ & Polarizability: & $67.6 \pm 0.5 \quad 10-24 \mathrm{~cm} 3$ \\
\hline Surface Tension: & $67.2 \pm 5.0$ dyne $/ \mathrm{cm}$ & Surface Tension: & $62.8 \pm 3.0$ dyne $/ \mathrm{cm}$ \\
\hline Molar Volume: & $414.8 \pm 5.0 \mathrm{~cm} 3$ & Molar Volume: & $438.3 \pm 3.0 \mathrm{~cm} 3$ \\
\hline R9.- & & R10.- & \\
\hline Density: & $1.3 \pm 0.1 \mathrm{~g} / \mathrm{cm} 3$ & Density: & $1.3 \pm 0.1 \mathrm{~g} / \mathrm{cm} 3$ \\
\hline Boiling Point: & $820.9 \pm 65.0^{\circ} \mathrm{C}$ at $760 \mathrm{mmHg}$ & Boiling Point: & $742.6 \pm 70.0^{\circ} \mathrm{C}$ at $760 \mathrm{mmHg}$ \\
\hline Vapour Pressure: & $0.0 \pm 3.1 \mathrm{mmHg}$ at $25^{\circ} \mathrm{C}$ & Vapour Pressure: & $0.0 \pm 2.5 \mathrm{mmHg}$ at $25^{\circ} \mathrm{C}$ \\
\hline Enthalpy of Vaporizat & tion: $\quad 123.4 \pm 3.0 \mathrm{~kJ} / \mathrm{mol}$ & Enthalpy of Vaporizati & $108.3 \pm 3.0 \mathrm{~kJ} / \mathrm{mol}$ \\
\hline Flash Point: & $450.2 \pm 34.3^{\circ} \mathrm{C}$ & Flash Point: & $402.9 \pm 35.7^{\circ} \mathrm{C}$ \\
\hline Index of Refraction: & 1.66 & Index of Refraction: & 1.637 \\
\hline Molar Refractivity: & $153.7 \pm 0.3 \mathrm{~cm} 3$ & Molar Refractivity: & $161.2 \pm 0.5 \mathrm{~cm} 3$ \\
\hline \#H bond acceptors: & 10 & \#H bond acceptors: & 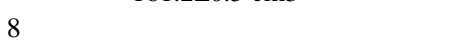 \\
\hline \#H bond donors: & 4 & \#H bond donors: & 0 \\
\hline \#Freely Rotating Bond & ds: & \#Freely Rotating Bond & ds: \\
\hline \#Rule of 5 Violations: & & \#Rule of 5 Violations: 2 & \\
\hline $\mathrm{ACD} / \log \mathrm{P}:$ & 4.15 & $\mathrm{ACD} / \log \mathrm{P}:$ & 6.18 \\
\hline $\mathrm{ACD} / \log \mathrm{D}(\mathrm{pH} 5.5):$ & 3.61 & $\mathrm{ACD} / \operatorname{LogD}(\mathrm{pH} 5.5): 5$ & 5.55 \\
\hline $\mathrm{ACD} / \mathrm{BCF}(\mathrm{pH} 5.5):$ & 327.32 & $\mathrm{ACD} / \mathrm{BCF}(\mathrm{pH} 5.5):$ & 9740.59 \\
\hline $\mathrm{ACD} / \mathrm{KOC}(\mathrm{pH} 5.5)$ & 2196.58 & $\mathrm{ACD} / \mathrm{KOC}(\mathrm{pH} 5.5):$ & 24923.9 \\
\hline $\mathrm{ACD} / \log \mathrm{D}(\mathrm{pH} 7.4):$ & 3.6 & $\mathrm{ACD} / \operatorname{LogD}(\mathrm{pH} 7.4):$ & 5.55 \\
\hline $\mathrm{ACD} / \mathrm{BCF}(\mathrm{pH} 7.4):$ & 317.64 & $\mathrm{ACD} / \mathrm{BCF}(\mathrm{pH} 7.4):$ & 9740.82 \\
\hline $\mathrm{ACD} / \mathrm{KOC}(\mathrm{pH} 7.4)$ & 2131.6 & $\mathrm{ACD} / \mathrm{KOC}(\mathrm{pH} 7.4): 2$ & 24924.5 \\
\hline Polar Surface Area: & $136 \AA 2$ & Polar Surface Area: & $122 \AA 2$ \\
\hline Polarizability: & $60.9 \pm 0.510-24 \mathrm{~cm} 3$ & Polarizability: & $63.9 \pm 0.510-24 \mathrm{~cm} 3$ \\
\hline Surface Tension: & $58.7 \pm 3.0$ dyne $/ \mathrm{cm}$ & Surface Tension: & $51.2 \pm 7.0 \mathrm{dyne} / \mathrm{cm}$ \\
\hline Molar Volume: & $416.7 \pm 3.0 \mathrm{~cm} 3$ & Molar Volume: & $449.0 \pm 7.0 \mathrm{~cm} 3$ \\
\hline
\end{tabular}

